\title{
A Case Study in Qatar for Optimal Energy Management of an Autonomous Electric Vehicle Fast Charging Station with Multiple Renewable Energy and Storage Systems
}

\author{
Abdulla Al Wahedi *(D) and Yusuf Bicer (D) \\ Division of Sustainable Development (DSD), College of Science and Engineering (CSE), Hamad Bin Khalifa \\ University (HBKU), Education City 5825, Doha, Qatar; ybicer@hbku.edu.qa \\ * Correspondence: amalwahedi@mail.hbku.edu.qa
}

Received: 14 July 2020; Accepted: 7 September 2020; Published: 30 September 2020

\begin{abstract}
E-Mobility deployment has attained increased interest during recent years in various countries all over the world. This interest has focused mainly on reducing the reliance on fossil fuel-based means of transportation and decreasing the harmful emissions produced from this sector. To secure the electricity required to satisfy Electric Vehicles' (EVs') charging needs without expanding or overloading the existing electricity infrastructure, stand-alone charging stations powered by renewable sources are considered as a reasonable solution. This paper investigates the simulation of the optimal energy management of a proposed grid-independent, multi-generation, fast-charging station in the State of Qatar, which comprises hybrid wind, solar and biofuel systems along with ammonia, hydrogen and battery storage units. The study aims to assess the optimal sizing of the solar, wind and biofuel units to be incorporated in the design along with the optimal ammonia, hydrogen and battery storage capacities to fulfill the daily EV demand in an uninterruptable manner. The main objective is to fast-charge a minimum of $50 \mathrm{EVs}$ daily, while the constraints are the intermittent and volatile nature of renewable energy sources, the stochastic nature of $\mathrm{EV}$ demand, local meteorological conditions and land space limitations. The results show that the selection of a $468 \mathrm{kWp}$ concentrated photovoltaic thermal plant, $250 \mathrm{~kW}$-rated wind turbine, $10 \mathrm{~kW}$ biodiesel power generator unit and $595 \mathrm{kWh}$ battery storage system, along with the on-site production of hydrogen and ammonia, to generate $200 \mathrm{~kW}$ power via fuel cells can achieve the desired target, with a total halt of on-site hydrogen and ammonia production during October and November and 50\% reduction during December.
\end{abstract}

Keywords: grid-independent; fast-charging station; electrical vehicle; modeling; simulation; optimization

\section{Introduction}

Transportation is the biggest emitter of environmental pollution in metropolitan districts [1], consuming about $62 \%$ of the oil produced globally and producing $6892 \mathrm{Mt}$ of $\mathrm{CO}_{2}$ emissions into the air [2]. This classifies transportation as the second greatest source of $\mathrm{CO}_{2}$ [3]. As per studies conducted by International Energy Outlook, transportation demand will rise till 2035 by $54 \%$, causing a significant global increase in fossil fuels' demand if alternative eco-friendly solutions are not adopted [4]. The environmental issues related to fossil-fuel exhaustion have increased worldwide motivation for deploying Electric Vehicles (EVs) as ecological and clean means of transportation. As a result, global EVs' sales grew from 320,000 in 2014 to 1.04 million in 2017 [5]. To encourage EV expansion, it is vital to accelerate the expansion of Fast Charging Stations (FCS) where EVs can be charged for 15-20 min [6]. Supplying FCS from the existing energy system imposes an extra burden on the electrical grid. Moreover, stochastic connections to charge EVs cause overloading at peak demand, creating instability and, ultimately, blackouts [7]. 
Those facts necessitate exploring additional resources for securing additional power to supply the rapidly increasing number of FCS [8]. As electricity is generated predominantly from fossil fuel-based sources such as petroleum, gas and coal, the substantial growth in the energy demand to supply the anticipated large number of FCS will expedite fossil fuel reserve exhaustion and cause severe ecological impacts. This fact triggers the need for expanding the deployment of sustainable renewable energy sources (RES) as alternative non-conventional and non-fossil-fuel-based solutions to fulfill FCS power demand.

RES are considered as the main element in any de-carbonization strategy [7]. Due to the stochastic nature of RES, their large-scale penetration at the supply end of the existing energy system can stress network performance by reducing power quality, causing voltage deviations and increasing power losses [4]. The increased penetration of photovoltaics (PV) and wind turbines (WT) in the network threatens the stable operation of distribution networks due to RES output fluctuation [9]. By contrast, investment costs [10], losses and voltage fluctuations [11] can be reduced dramatically by installing them near the load. As a result, the roll-out of grid-independent renewable energy-based FCS to fulfill the rapid expansion of EV adoption around the globe seems to be a promising solution from the technical, economic and environmental perspectives. The hybridization of multiple renewable energy-based subsystems with various energy storage options connected to the grid have been explored and developed for many years. Nevertheless, the study of grid-independent FCS powered by both RES systems and multiple energy storage units is relatively recent.

The opportunities to use locally distributed hybrid renewable energy resources to supply EV charging stations instead of connecting to the grid can be summarized as follows:

- Prevent fossil fuel-based power generation expansion to fulfill EVs' increasing charging demand and associated environmental pollution.

- Despite the availability of a national-level power surplus, many cities within the same nation might suffer from excess stress on the local electricity distribution network with no possibility of connecting to the grid.

- Avoid costly infrastructure investments due to a lack of nearby connection possibilities for the existing grid.

- Promote distributed generation to avoid technical malfunctions and failures due to overloading the existing network and transformers.

- Exempt charging station owners from paying carbon taxes by investing in establishing independent renewable energy-based power generation systems instead of connecting EV charging stations to the existing grid.

- Improve system resilience against possible grid interruptions during peak demand.

It is important to intensify the theoretical and experimental studies in this field to improve the awareness of these joint subsystems, where the proposed designs must be modeled, simulated and optimized considering real-life conditions to determine their feasibility before practical implementation.

Many studies investigated and modeled grid-dependent EV charging stations, where Genetic Algorithm (GA) and Particle Swarm Optimization (PSO) tools were used considering various economic and technical constraints [12]. One study [4] used an improved version of the same tools for the optimal allocation and sizing of RES and EV charging stations, considering voltage fluctuations and EV charging costs among other factors. GA-PSO optimization tools were used as well [7] to determine Charging Station (CS) locations and capacities when considering distributed RES, EV users' satisfaction degree and distribution network technical constraints.

The study by Gong et al. [7] proposed an uncertainty model using Set Pair Analysis (SPA) for predicting RES outputs. Considering EVs as mobile energy storage units, the study evaluated a smart charging strategy for reducing RES fluctuations. The study by Liu et al. [13] used an Adaptive Particle Swarm Optimization (APSO) algorithm for placing and sizing CSs, considering geographic information, construction and operation costs. Moreover, another study [14] developed a Mixed-Integer Non-Linear Programming (MINLP) model for the optimal locating and sizing of FCS, considering 
urban roads, electrical substation locations, development cost and electrical grid loss. The study by Haddadian et al. [15] proposed a Mixed-Integer Linear Programming (MILP) optimization tool to examine a large-scale integration of wind energy and EVs. The study concluded that aggregated storage facilities assist in reducing grid operation costs and power system peak demands. The simulation results of the Lyapunov optimization technique using different wind power generation profiles in the study by Jin et al. [16] showed that EV charging scheduling can reduce both charging cost and charging request delays. In a study by Liu et al. [17], an optimization model was built to determine both peak-valley timing and price, to develop a controlled EV charging strategy considering local PV and WT outputs.

On the other hand, very few studies related to the investigation and modeling of off-grid charging stations have been performed [18]. The study by Karmaker et al. [19] used HOMER Pro software [20] to conduct a techno-economic and environmental feasibility study to offer a low cost charging station based on hybrid renewables, compared against a conventional coal-fired energy-based charging station. In the study by Mehrjerdi [18], they used an MILP model for finding the optimal rated powers of a solar system and a diesel generator with minimum investment cost for grid-independent RES-based EV and hydrogen vehicle charging stations.

As per reviewed literature, the modeling, simulation and optimization of off-grid charging stations is a crucial topic, which requires additional study to explore intensely. This study's specific objectives can be summarized as follows:

- $\quad$ Propose an off-grid, hybrid renewable energy-based FCS powered by solar, wind and biofuel energy.

- Select a suitable solar system and wind turbine based on space limitations and site-specific meteorological conditions.

- Employ the optimal capacities of electrochemical and chemical energy storage options along with associated Fuel Cells (FC) for sustaining stable operation during night times and based on various environmental conditions.

- Develop hourly modeling and simulation programming tools for selecting the optimum capacities of RES and energy storage, and to determine the overall operation strategy to fast-charge a minimum of 50 EVs per day.

- Case study application of the developed optimization tool in Qatar to examine its reliability.

\section{Case Study and System Description}

In this section, the details about the case study in Qatar are presented, and then, the proposed system consisting of several renewable energy sources and subsystems is described.

\subsection{Case Study}

With a population of 2.64 million [21], 11,521 $\mathrm{km}^{2}$ area [22] and over 1.5 million fossil fuel-based conventional vehicles [23], Qatar announced its "Green Car Initiative" in May 2017 to promote the roll-out of carbon-free car usage, aiming for 10\% EVs by 2030 [24]. From 2012 to 2017, the number of vehicles in Qatar grew by 12\% to a total of 1.5 million in 2017 [23]. With the same percentage increase, the number of vehicles will reach 2.7 million by 2022, out of which $2 \%$ to $4 \%$ are expected to be EVs [25]. By the same year, the number of charging stations is expected to become 400 stations [26]. In order to secure the considerable additional energy demand required to charge the anticipated number of EVs without expanding conventional power generation plants or degrading the existing network in a timely manner, grid-independent CSs powered by RES along with optimization, simulation and modeling tools to assist in designing and distributing CSs all over the country are required. Assuming that in 2022, 3.5\% of the overall vehicles in Qatar will be EVs, about 108,000 EVs will be on the road. Considering $80 \%$ of the EVs shall satisfy their charging needs at workplaces and homes [27], the other $20 \%$, representing $21,600 \mathrm{EVs}$, shall need city and on-road fast-charging stations. In distributing this 
number over 400 charging stations, each station must charge about $50 \mathrm{EVs}$ as a minimum number daily. Therefore, the minimum number of EVs to be served by a CS is selected as $50 \mathrm{EVs}$ in this study.

A daily charging demand of $35 \mathrm{kWh}$ per EV was considered in this study based on the following facts:

1. The majority of EVs will be of medium size with a $50 \mathrm{kWh}$ battery capacity, which is the upper limit for this size [28].

2. Most on-the-move EV drivers start to look for a charging station when the State of Charge (SoC) of their batteries reaches $20 \%$, aiming for an $80 \%$ SoC level within $20 \mathrm{~min}$.

\subsection{System Description}

The present study proposes a stand-alone, fast-charging station with solar, wind and biofuel power generator technologies in a hybrid configuration for power generation in order to satisfy the daily fast-charging demand of EVs as illustrated in Figure 1.

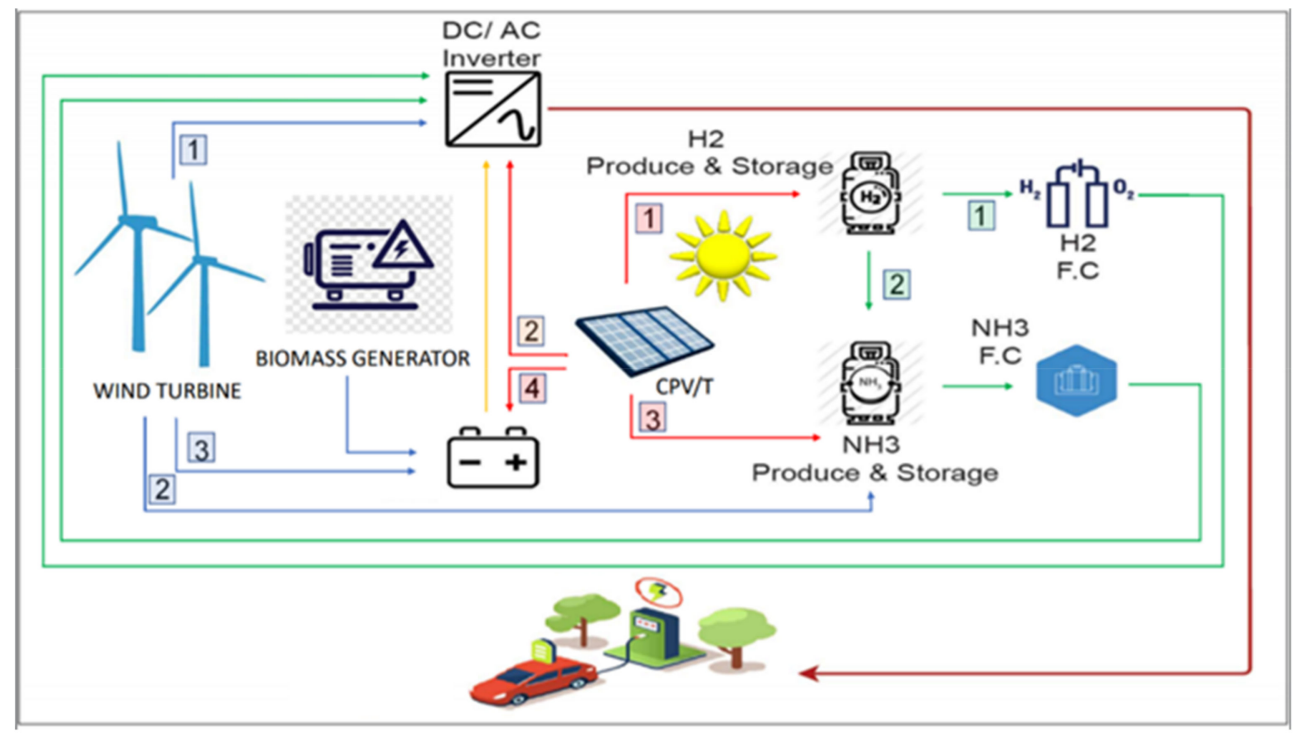

Figure 1. Stand-alone fast charging station schematic diagram.

Multiple energy storage systems-namely, ammonia, hydrogen and battery storage subsystemsare incorporated to secure a continuous supply of power even if there is not sufficient wind or solar energy.

The proposed design can be divided into the following four subsystems:

\subsubsection{RES Systems}

They represent components that generate electricity directly from renewable resources such as wind and solar. Considering the site conditions of Qatar, the three types of RES used in the design as direct supply sources are listed below, where the justifications for selecting each are elaborated as well:

- PV system: Two PV technologies are investigated in this study, namely, PV and Concentrated Photovoltaic Thermal (CPV/T) systems. Although CPV/T has better electrical efficiency, due to relatively higher costs, both are investigated. Since the electrical output of this system is DC power, it is used directly for supplying an electrolyzer, which requires DC input, and the extra power is used for EV charging, $\mathrm{NH}_{3}$ production and battery storage. The $\mathrm{PV}$ system is selected in the design in Qatar due to the following:

- Qatar's geographical location is on the Sun Belt region of the world, where plentiful solar power from the sun can be harvested throughout the year for generating electricity. Based on the meteorological data extracted with the HOMER Pro software [20], the monthly average solar Global Horizontal Irradiance (GHI) is reflected in Figure 2. 
- Need for limited space requirements for small-scale plants.

- Short construction time compared to other RES options.

- Due to the efficiency increase and dramatic cost reduction of PV panels globally during recent years, solar technology is leading the competition against other electricity generation sources.

- WT plant: To complement the PV system, particularly during night times and cloudy days, a WT is integrated in the design. The output is used for EV charging, $\mathrm{N}_{2}$ and $\mathrm{NH}_{3}$ production and battery storage. The WT plant is selected in the design in Qatar due to the following:

- To complement the first source during night times and cloudy days.

- Due to the efficiency increase and cost reduction globally during recent years.

- The availability of WT models in the market that can generate sufficient electricity with a $5.6 \mathrm{~m} / \mathrm{s}$ wind speed, which is the average wind speed in the selected location of Qatar.

- Limited space requirements for small-scale plants.

- Short construction time compared to other RES options.

- Based on the meteorological data extracted from the HOMER Pro software [20], the monthly average speed in Qatar is reflected in Figure 3.

- Biofuel power generator: A backup generator operated by biodiesel is used as backup source only during unfavorable weather conditions when the supply from other incorporated sources is not sufficient to meet the required demand. It is operated temporarily, where the electricity is produced from the combustion of biodiesel to complement the other renewable sources for meeting the shortfall demand. Biodiesel has a higher heating value (HHV) of 40,700 kJ/kg, which is only $9 \%$ less than petroleum diesel's HHV [29]. The biodiesel generator is selected in the design in Qatar due to the following:

- It has low biodiesel volume requirements since it is used as a backup source in case the demand is not fulfilled by the primary energy sources and storage systems.

- The required quantities can be produced locally by processing restaurant waste oil and animal fat.

Based on the geographical location of Qatar and site-specific conditions, other renewable sources such as geothermal and hydropower are not viable for implementation.

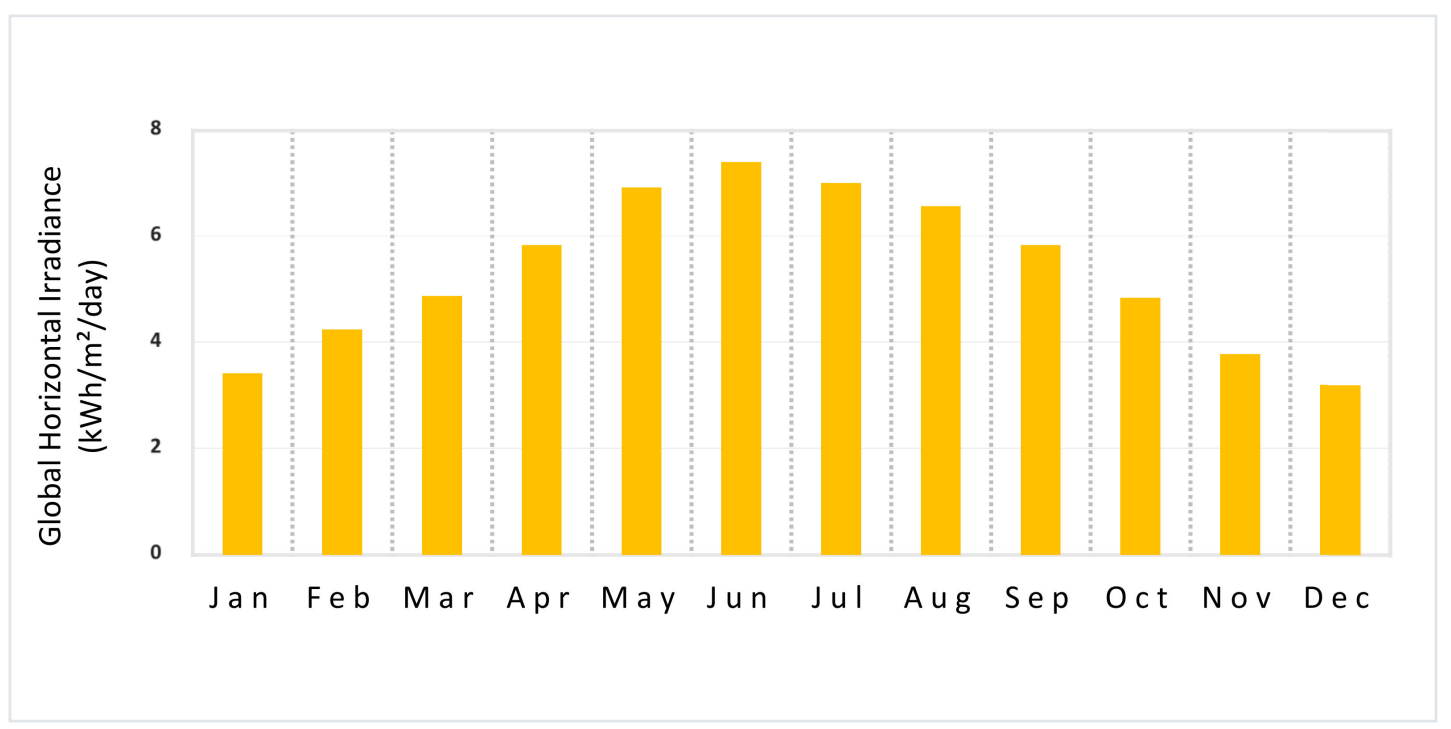

Figure 2. Monthly average solar Global Horizontal Irradiance (GHI) in Qatar. 


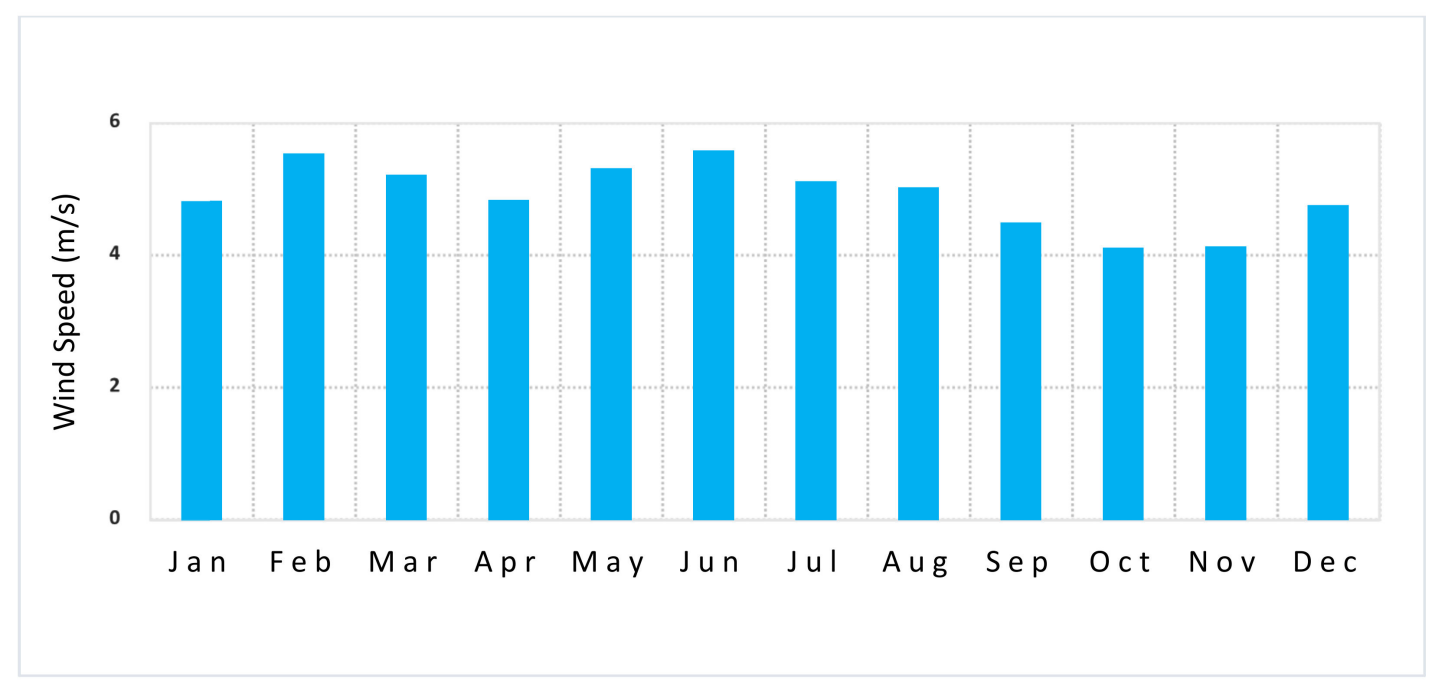

Figure 3. Monthly average speed in Qatar.

\subsubsection{Chemicals Production Subsystem}

The surplus energy produced from the system is utilized for producing chemicals to store energy in chemical form for usage during supply shortage from the main RES. The associated main components of this subsystem are presented below:

- Electrolyzer: A Proton Exchange Membrane (PEM) electrolyzer unit fed with water from a tank is incorporated to decompose water into $\mathrm{H}_{2}$ and $\mathrm{O}_{2}$. The unit is supplied with DC power produced from a PV system, and the produced chemicals are stored separately in gas form.

- Air separator: Air is decomposed into $\mathrm{N}_{2}$ and $\mathrm{O}_{2}$ through a cryogenic air separation process, where $\mathrm{N}_{2}$ is used for $\mathrm{NH}_{3}$ production and $\mathrm{O}_{2}$ is stored in a tank for later use in the fuel cells.

- Haber-Bosch plant: $\mathrm{NH}_{3}$ synthesis is performed through the Haber-Bosch process, where the $\mathrm{H}_{2}$ produced from the electrolyzer and the $\mathrm{N}_{2}$ produced from the air separation are reacted to produce $\mathrm{NH}_{3}$.

\subsubsection{Energy Storage Subsystem}

The optimal management of the energy harvested from the main RES requires storing surplus energy in appropriate forms for later use. Three types of energy storage technologies are incorporated in the design, which are listed below:

- Battery storage: It represents the electro-chemical storage technology used in the design. A Lithium-Ion (Li-ion) battery system is used to store the excess daily energy produced, whether from biofuel, wind or solar system, for later usage whenever needed.

- $\mathrm{H}_{2}$ storage: This represents one of the two chemical storage technology types used in the design. The produced $\mathrm{H}_{2}$ from the electrolyzer is stored in a tank in gas form, which is used for direct and indirect electricity conversion.

- $\mathrm{NH}_{3}$ storage: The produced $\mathrm{NH}_{3}$ from the Haber-Bosch process is initially stored in liquid form, which is used for direct electricity conversion after evaporation into gas form. The storage pressure and temperature are $1000 \mathrm{kPa}$ and $25^{\circ} \mathrm{C}$, respectively.

\subsubsection{Energy Conversion Subsystems}

The three components integrated in the system to convert the energy stored in electro-chemical form or chemical form into electricity are listed below: 
- $\mathrm{H}_{2} \mathrm{FC}$ : A polymer exchange membrane (PEM) $\mathrm{H}_{2} \mathrm{FC}$ is incorporated in the design, where in the case of a shortage of supply from solar and wind during night times and unfavorable periods, first priority is given to the conversion of the stored $\mathrm{H}_{2}$ into electricity through the $\mathrm{H}_{2} \mathrm{FC}$ to produce energy for charging EVs.

- $\mathrm{NH}_{3} \mathrm{FC}$ : Second priority is given to a polymer exchange membrane (PEM) $\mathrm{NH}_{3} \mathrm{FC}$ to convert the stored $\mathrm{NH}_{3}$ into electricity to produce energy for charging EVs in the case of a supply shortage from solar and wind during night times and unfavorable periods.

- Battery Storage System (BSS): A shortage of supply from solar, wind, $\mathrm{H}_{2}$ and $\mathrm{NH}_{3}$ would result in supplying energy for EV charging from the BSS, which is given third and last priority among the incorporated energy storage systems.

The scope of this paper is to determine, through modeling and simulation, the optimal sizing and operation strategy for the proposed renewable energy-based off-grid FCS, considering space limitations and the climate circumstances of the State of Qatar. The developed method can be applied globally as well, where the site-specific conditions of another country can be used as input variables and constraints.

\section{Methodology}

A detailed technical assessment has already been conducted by the authors in a previous study, where the energetic efficiencies of the subsystems and overall system for the proposed design were determined [30]. The study quantified the efficiency of each subsystem's component, where the series of energy conversions in each loop within the proposed hybrid design were considered. The Engineering Equation Solver (EES) software [31] was used for thermodynamic analysis of the proposed system, based on which the efficiencies of the subsystems were simulated and calculated. The resulting electrical efficiencies of the main components and the overall system illustrated in Table 1 appear to be promising compared to the results of similar studies in the literature.

Table 1. Efficiencies of the main components and subsystems.

\begin{tabular}{cc}
\hline Description & Value \\
\hline CPV/T electrical & $34 \%$ \\
\hline Wind turbine electrical & $42 \%$ \\
\hline DC-AC inverter & $95 \%$ \\
\hline Battery charging and discharging & $95 \%$ \\
\hline Electrolyzer & $65 \%$ \\
\hline $\mathrm{H}_{2}$ fuel cell & $77 \%$ \\
\hline $\mathrm{NH}_{3}$ fuel cell & $72 \%$ \\
\hline $\mathrm{Overall} \mathrm{system}$ & $45 \%$ \\
\hline
\end{tabular}

The methodology followed for developing the optimization tool in Excel for this study is shown in Figure 4, where each step is subsequently elaborated. 


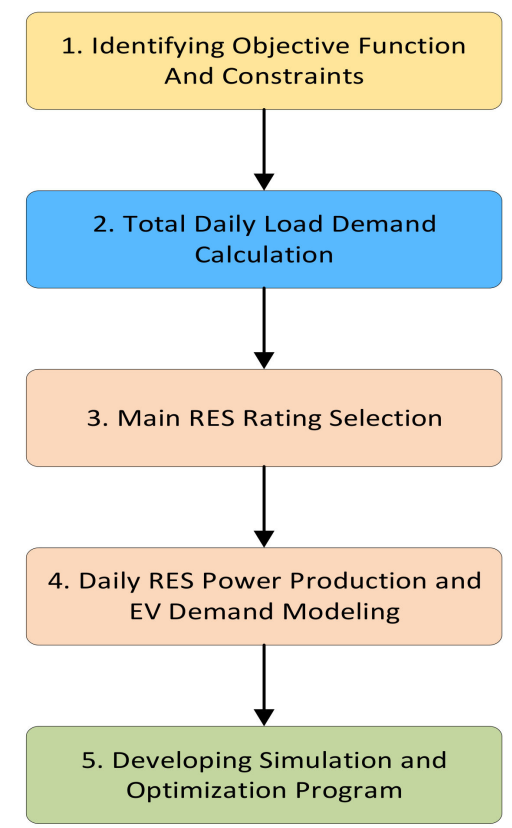

Figure 4. Methodology followed for optimizing the electricity supply to Electric Vehicle (EV) Fast Charging Stations (FCS).

The following steps are considered for an optimization route:

1. Identifying objective function and constraints: The first step is to identify the optimization objective function of the study and the associated constraints for which the formulas and algorithms must be developed as elaborated below:

- The main objective of the study is to produce, with the deployed RES, sufficient electricity to charge 50 EVs per CS per day, which is represented by Equation (1):

$$
\mathrm{PE}_{\text {Total }}=\mathrm{PE}_{\mathrm{Solar}}+\mathrm{PE}_{\text {Wind }}+\mathrm{PE}_{\mathrm{H} 2 \_\mathrm{FC}}+\mathrm{PE}_{\mathrm{NH} 3 \_\mathrm{FC}}+\mathrm{PE}_{\text {Battery }}+\mathrm{PE}_{\text {Bio-generator }}
$$

The above function calculates the optimal amount of electricity that can be produced by different selected RES portfolios and sizing, where the following constraints must be met.

- Constraints: the set of equations or conditions that must be considered while achieving the defined objective are as follows:

- The intermittent and volatile nature of RES, which is represented by Equations (2) and (3) below:

$$
\begin{gathered}
0 \leq \mathrm{PE}_{\text {Solar }} \leq \mathrm{PE}_{\text {Solar during maximum irradiation }} \\
0 \leq \mathrm{PE}_{\text {Wind }} \leq \mathrm{PE} \mathrm{E}_{\text {Wind during rated wind speed }}
\end{gathered}
$$

- The daily electricity produced from the $\mathrm{H}_{2}$ FC should not exceed the maximum capacity set for $\mathrm{H}_{2}$ storage, as indicated in Equation (4) below:

$$
0 \leq \mathrm{PE}_{\mathrm{H} 2 \_\mathrm{FC}} \leq \mathrm{PE}_{\mathrm{H} 2 \_\mathrm{FC}} \text { with full } \mathrm{H} 2 \text { storage }
$$

- The daily electricity produced from the $\mathrm{NH}_{3} \mathrm{FC}$ should not exceed the maximum capacity set for $\mathrm{NH}_{3}$ storage, as indicated in Equation (5) below:

$$
0 \leq \mathrm{PE}_{\mathrm{NH} 3 \_\mathrm{FC}} \leq \mathrm{PE}_{\mathrm{NH} 3 \_\mathrm{FC}} \text { with full } \mathrm{NH} 3 \text { storage }
$$


- The daily electricity produced from the batteries should not exceed the maximum set storage capacity, as indicated in Equation (6) below:

$$
0 \leq \mathrm{PE}_{\text {Battery }} \leq \mathrm{PE}_{\text {Battery with full battery storage }}
$$

- The daily electricity produced from bio-generator should not exceed the rated capacity multiplied by $24 \mathrm{~h}$, as indicated in Equation (7) below:

$$
0 \leq \mathrm{PE}_{\text {Bio-generator }} \leq \mathrm{Bio}-\text { generator rating in } \mathrm{kW} \times 24 \mathrm{~h}
$$

- Regarding space limitations, the area should not exceed $1500 \mathrm{~m}^{2}$ to match standard fueling station area, as indicated in Equation (8) below:

$$
0 \leq \mathrm{EV}_{-} \mathrm{CS}_{\text {Area }} \leq 1500 \mathrm{~m}^{2}
$$

2. Total daily load demand calculation: The daily load consists of the following types of loads:

- EV charging load represents the minimum daily load required to charge $50 \mathrm{EVs}$ with $35 \mathrm{kWh}$. This load is calculated as per Equation (9) below:

$$
\text { Daily EV charging load }=35 \mathrm{kWh} \times 50=1750 \mathrm{kWh}
$$

- $\mathrm{H}_{2}$ production load represents the additional power required for producing and storing the $\mathrm{H}_{2}$ necessary to produce electricity from the $\mathrm{H}_{2} \mathrm{FC}$ during a RES supply shortage. Based on the optimal amount of energy dedicated by the optimization program for $\mathrm{H}_{2}$ production and storage from the total daily surplus energy, the daily electricity produced from the $\mathrm{H}_{2}$ FC can be determined.

- $\mathrm{NH}_{3}$ production load represents the additional power required for producing and storing the $\mathrm{NH}_{3}$ necessary to produce electricity from the $\mathrm{NH}_{3}$ FC during a RES supply shortage. Based on the optimal energy amount dedicated by the optimization program from the total daily surplus energy for $\mathrm{NH}_{3}$ production and storage, the daily electricity produced from the $\mathrm{NH}_{3}$ FC can be determined.

The developed optimization program should ensure that the total daily produced energy by the system is sufficient to fulfill the total daily demand, which is expressed by Equation (10) below:

$$
\mathrm{PE}_{\text {Total }} \geq \mathrm{EV}_{\text {demand }}+\mathrm{H}_{2} \text { Production }_{\text {demand }}+\mathrm{NH}_{3} \text { Production }_{\text {demand }}+\text { BSS Charging }_{\text {demand }}
$$

3. Main RES capacity selection: Based on the site-specific conditions, the optimal solar and wind plants are selected, following the steps below:

- $\quad$ PV systems: The PVSyst software [32] is used to select and simulate the maximum possible electricity production per day with different available solar systems and associated battery storage capacities, considering the meteorological conditions of Qatar and typical CS space limitations. As per the PVSyst results, two types of solar systems-namely, PV type and $\mathrm{CPV} / \mathrm{T}$ type-are recommended for the initial design, along with a $408 \mathrm{kWh}$ Li-ion battery. The optimal PV type and BSS capacity for the overall integrated design shall be investigated eventually in this study.

- Wind plant: Based on yearly wind speed profile in Qatar and considering typical charging station aesthetics and space limitations, a $250 \mathrm{~kW}$ WT system is selected from the market [33], where the technical specifications of the selected turbine are in accordance with the wind speed range in Qatar. 
The technical characteristics of the initially selected WT, PV, CPV/T and BSS are given in Table 2 below.

Table 2. Main components' technical characteristics.

\begin{tabular}{|c|c|}
\hline Parameter & Description/Value \\
\hline \multicolumn{2}{|c|}{ PV } \\
\hline Array global power & $251 \mathrm{kWp}$ \\
\hline Installed area & $1496 \mathrm{~m}^{2}$ \\
\hline \multicolumn{2}{|c|}{$\mathrm{CPV} / \mathrm{T}$} \\
\hline Array global power & $468 \mathrm{kWp}$ \\
\hline Installed area & $1497 \mathrm{~m}^{2}$ \\
\hline \multicolumn{2}{|l|}{ Battery storage system } \\
\hline Battery Type & Lithium-Ion \\
\hline Discharging min. SOC & $20.0 \%$ \\
\hline \multicolumn{2}{|c|}{ Wind turbine } \\
\hline Capacity-Axis type & $250 \mathrm{~kW}$-Horizontal \\
\hline Cut-in wind speed & $2.5 \mathrm{~m} / \mathrm{s}$ \\
\hline Rated wind speed & $7.5 \mathrm{~m} / \mathrm{s}$ \\
\hline Cut-out wind speed & $25 \mathrm{~m} / \mathrm{s}$ \\
\hline Wind turbine rotor diameter & $54 \mathrm{~m}$ \\
\hline
\end{tabular}

\section{Daily RES power production and EV demand modeling:}

- $\quad P V$ and $C P V / T$ power production modeling: Based on the hourly generated electricity data for a year extracted from PVsyst for the two selected solar PV types, the daily power curves for both PV systems are modeled using the Excel program. Since this fundamental part of the program will guide all the subsequent steps, the modeling results generated from PVSyst for the PV and CPV/T systems for randomly selected days are compared with the ones generated from the developed Excel program for the same respective days. Both programs generated identical graphs, which validate the input modeling accuracy generated with the Excel program. The average daily energy produced by the PV and CPV/T systems is 1415 and $1520 \mathrm{kWh}$, respectively.

- WT power production modeling: Wind data obtained from the Supreme Committee for Delivery \& Legacy in Qatar [34] and Qatar Civil Aviation Authority [35] are used as inputs for Equation (11), derived from the wind power Equation (12), indicated below, to calculate the hourly power generated by the selected WT.

$$
\frac{\mathrm{P}_{1}}{\mathrm{P}_{2}}=\frac{\left(\mathrm{V}_{2}\right)^{3}}{\left(\mathrm{~V}_{1}\right)^{3}} \rightarrow \mathrm{P}_{2}=\mathrm{P}_{1} \times \frac{\left(\mathrm{V}_{1}\right)^{3}}{\left(\mathrm{~V}_{2}\right)^{3}}
$$

where $\mathrm{P}_{1}=$ rated wind turbine power, $\mathrm{V}_{1}=$ rated wind speed and $\mathrm{P}_{2}=$ calculated power in $\mathrm{V}_{2}$ wind speed.

$$
\mathrm{P}=0.5 \times \rho \times \mathrm{A} \times \mathrm{Cp} \times \mathrm{V}^{3} \times \mathrm{Ng} \times \mathrm{Nb}
$$

where $\rho=$ air density in $\mathrm{kg} / \mathrm{m}^{3}, \mathrm{~A}=$ rotor swept area $\left(\mathrm{m}^{2}\right), \mathrm{Cp}=$ coefficient of performance, $\mathrm{V}=$ wind velocity $(\mathrm{m} / \mathrm{s}), \mathrm{Ng}=$ generator efficiency and $\mathrm{Nb}=$ gear box bearing efficiency.

The daily power curve for a WT is modeled using Equation (11) in an Excel program, where the average daily energy produced by a $250 \mathrm{~kW}$ WT in Qatar in a year is found to be $1450 \mathrm{kWh}$. The yearly profiles for the PV, CPV/T and WT systems based on the monthly average data for each are reflected in Figure 5 below. 


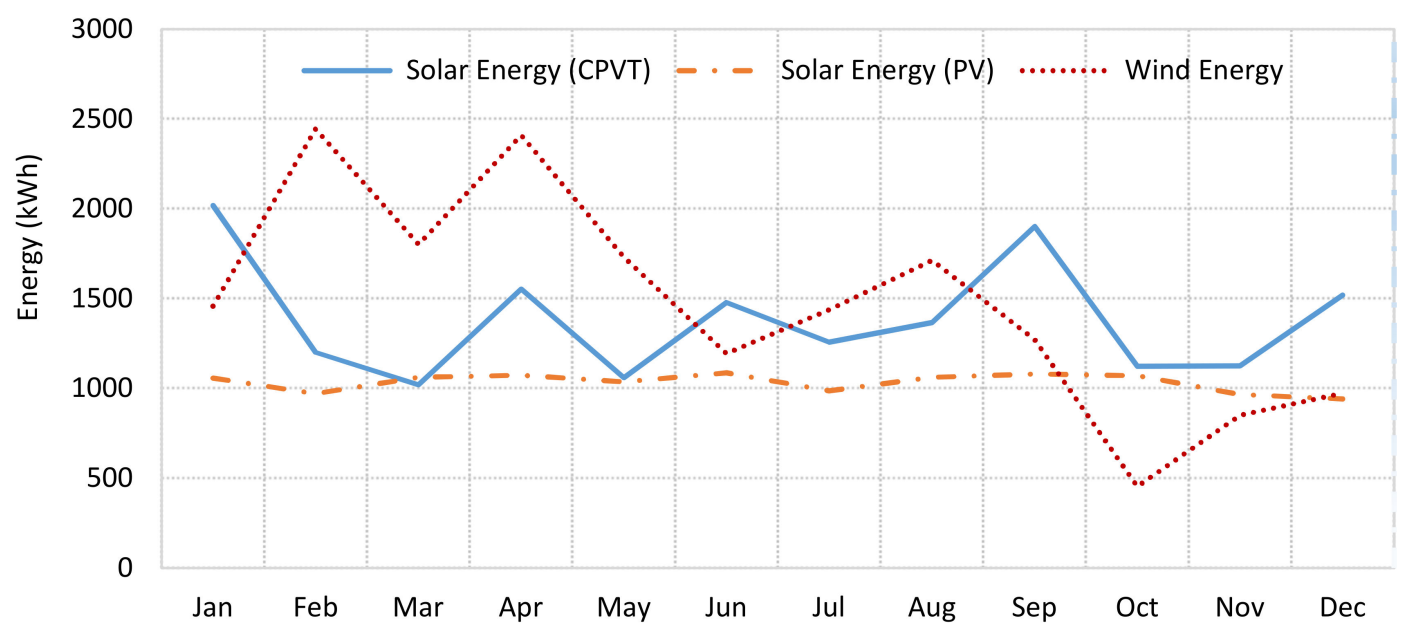

Figure 5. Selected PV, CPV/T and WT systems' yearly energy production profiles in Qatar.

- $\quad E V s^{\prime}$ daily load demand modeling: The total daily load demand of $1750 \mathrm{kWh}$ for charging 50 EVs must be modeled with a realistic curve. Due to the non-availability of EVs and CSs in Qatar, the daily local EV demand profile cannot be obtained. Moreover, it would not be appropriate to represent the data of combustion engine vehicles visiting gas stations in Qatar to model EV charging trips to CSs. Therefore, the probability density function of EV charging demand is extrapolated from a realistic daily demand profile for EVs arriving at CSs in study [36]. Based on this, a stochastic modeling curve representing a realistic daily demand profile for 50 EVs arriving at CSs is determined. Figure 6 illustrates the stochastic model used in this study to represent the daily EV demand.

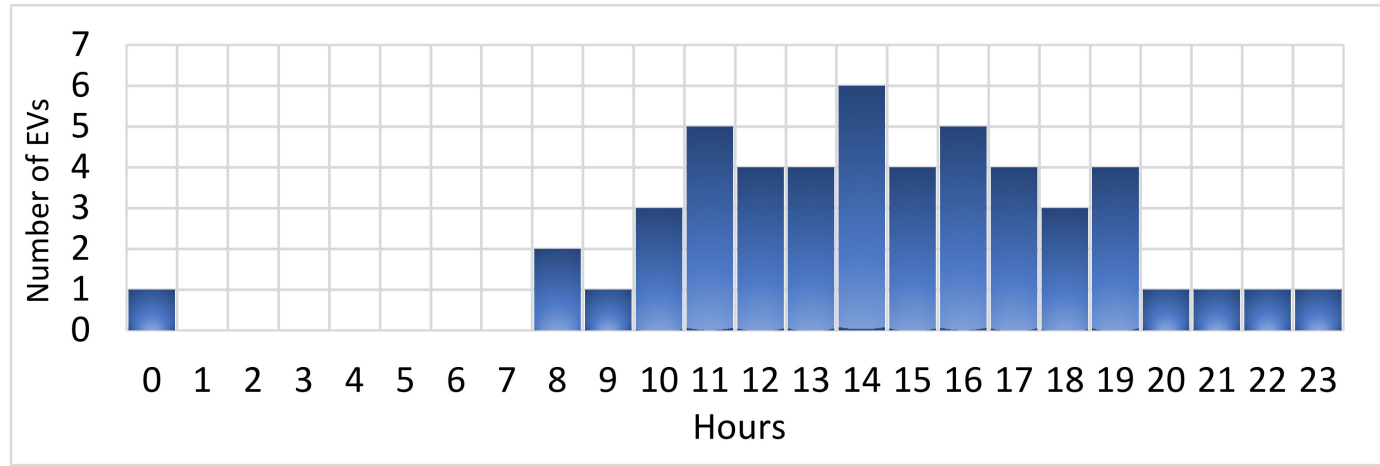

Figure 6. Stochastic EV demand model.

In low voltage networks, a minute-by-minute representation of load and generation would be more appropriate than hourly representation to consider sudden changes in the analysis. However, the main focus of this study is to assess the sizing of each RES and energy storage method incorporated in an off-grid charging station and the optimal management of the energy produced and consumed to fulfill the daily EV fast charging demand. Therefore, an hourly estimation of the average EVs arriving a charging station is considered similar to many other studies in the literature [36]. In the absence of minute-by-minute EV demand data, it would be difficult to model and simulate the load demand, based on which the entire study is carried out.

Similarly, the solar irradiation and wind speed data available in the literature and specialized software were obtained on an hourly basis. It would be difficult to model and simulate the output from RES in the absence of such data obtained on a minute-by-minute basis, which is a fundamental part of the entire study. 
5. Developing a daily operation simulation module: Prior to developing a programing code to simulate the energy produced and consumed hourly by the proposed design for a day, a flowchart prioritizing the sequence of the associated processes is developed, where the following operation priorities are considered:

- Since the solar system generates DC power, it is used directly during day times for producing $\mathrm{H}_{2}$.

- To better utilize the relatively large power generated from solar and wind sources during day times, first priority is given for producing chemicals $\left(\mathrm{H}_{2}\right.$ and $\left.\mathrm{NH}_{3}\right)$, followed by EV charging and, finally, battery charging.

- Since biomass is a more reliable and available RES with easier storage, a biofuel power generator is incorporated in the design as a stand-by resource to back up the overall system during unfavorable weather conditions.

- To avoid large biofuel power generator capacities, the generator is operated for $24 \mathrm{~h}$ during supply shortage days and it is only used to charge the BSS instead of for direct EV charging.

The modeling and simulation of energy storage charging is based on the following priority criteria:

- Energy from solar system: During the daytime, priority for the energy generated by the solar system is given to producing and storing $\mathrm{H}_{2}$ to directly utilize the generated DC voltage from the PV panels, followed by producing and storing $\mathrm{NH}_{3}$ and, finally, battery storage.

- Energy from wind turbine: Priority for the energy generated by wind turbine is given to producing and storing $\mathrm{NH}_{3}$, followed by battery storage.

- Energy from biofuel power generator: The energy generated from the backup bio-generator is used for battery storage.

On the other hand, the modeling and simulation of energy storage discharging is based on the principle of using energy storage systems whenever the produced energy from the RES is not sufficient to fulfil EV charging demand, where energy discharging priority is given to the $\mathrm{H}_{2} \mathrm{FC}$, followed by the $\mathrm{NH}_{3} \mathrm{FC}$ and finally the batteries. Based on the above-stated operation criteria, the operation priority flowchart illustrated in Figure 7 is developed.

Based on the hourly power supply and demand data along with the predefined operation priorities, formulas and algorithms are developed in Excel software, considering the previously stated objective function and constraints, to calculate and simulate the hourly power production and consumption of the proposed design for a day.

6. Developing an annual operation simulation module: Annual simulation is the aggregation of daily simulation calculations, which, in turn, depends on two factors: the status of the storage systems at the end of the previous day and the varying amount of energy generated from the RES based on the daily metrological conditions. Accordingly, a flowchart representing a step-by-step programing process is developed and illustrated in Figure 8.

Using Visual Basic programming code, formulas and algorithms are developed to repeat the daily simulation of the produced and consumed energy, considering the above-highlighted two factors for a complete year.

The developed comprehensive simulation model is used to assess the optimal energy storage capacities, PV system type and size, biofuel power generator rating and charging station operation strategy to achieve the desired objectives of this study. Figure 9 illustrates the seven steps followed to achieve those objectives, where each step's objective and achieved results are discussed in the following section. 


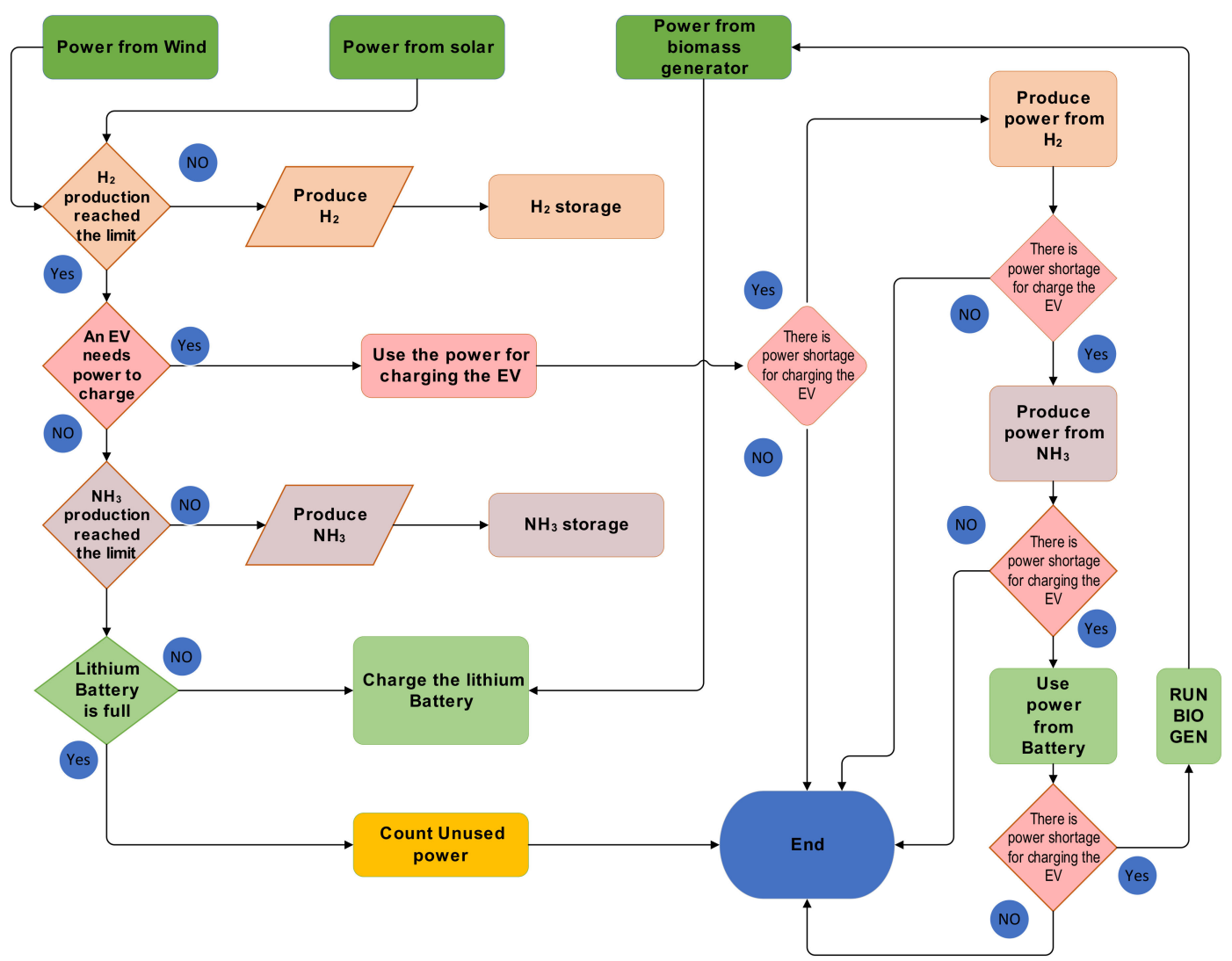

Figure 7. Operation priority flowchart.

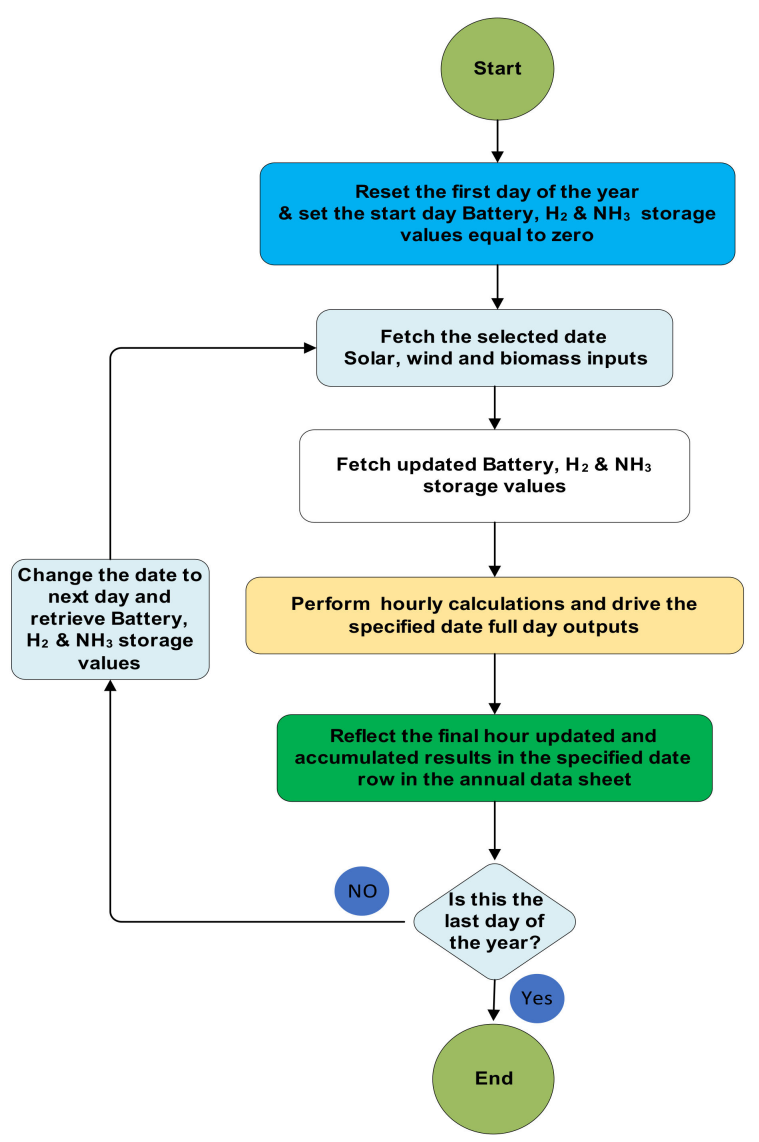

Figure 8. Annual simulation code flowchart. 


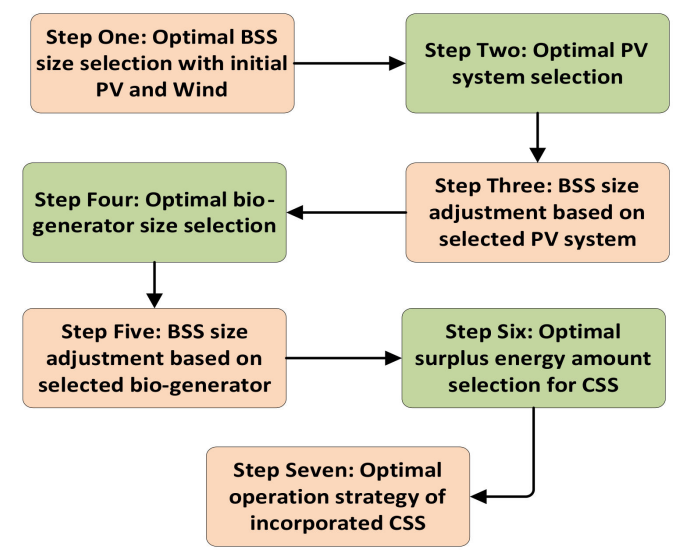

Figure 9. Seven-step approach to achieve the study's objectives.

\section{Results and Discussions}

The program is designed with an interactive dashboard interface, where multiple decision variables can be adjusted to simulate and evaluate different scenarios for optimal decision-making. The decision variables include RES ratings, energy storage, EV battery charging and stochastic EV demand. Based on the steps indicated in Figure 9, appropriate variables are adjusted with respect to each step, and the results achieved through modeling and simulation are discussed in this section.

- Step one-optimal BSS size selection with initial PV and WT: Since the $408 \mathrm{kWh}$ battery capacity suggested by PVSyst is based on integrating only a PV system and prior to incorporating the WT in the design, it is essential to determine the optimal battery size for the system after incorporating the selected WT. The optimal battery size ensures that there is not an undersized battery capacity causing supply shortages despite the availability of storable and non-dispatchable surplus energy from RES. Additionally, it ensures that no additional capacity is installed and left without usage, to avoid unnecessary investment costs and the associated negative environmental impact.

Setting the battery storage capacity to zero initially, the program is simulated to calculate, for each day, the total surplus energy during periods where the produced energy is more than the demand and the total energy shortage during periods where the produced energy is less than the demand. For the days where the surplus energy is found equal to or more than the demand shortage, the energy shortage value is recorded as the optimal battery capacity for those days. For the days where the surplus energy is found less than the demand shortage, the surplus energy value is recorded as the optimal battery capacity for those days. The maximum recorded optimal battery value in a year is found $670 \mathrm{kWh}$, which is selected as the optimal battery capacity for the whole year. To validate the selected value as the optimal battery size, multiple battery capacities are simulated using the developed program. For each simulated capacity, the number of EVs not able to charge annually is recorded. Starting with no battery storage, the number of EVs that are not able to be charged annually is found to be $4,155 \mathrm{EVs}$, which represents $22.8 \%$ of the annually targeted number of EVs. Multiple simulation with increasing battery capacity gradually verified that $670 \mathrm{kWh}$ is the optimal battery capacity, where the number of EVs that are not able to be charged annually is reduced dramatically to 231 EVs, which represents $1.27 \%$ of the annually targeted number of EVs. An additional $10 \%$ battery capacity increase from this value reduces the number of EVs that are not able to be charged annually by two EVs only. Figure 10 illustrates the one-year simulation for the selected RES and BSS so far and the associated results. 


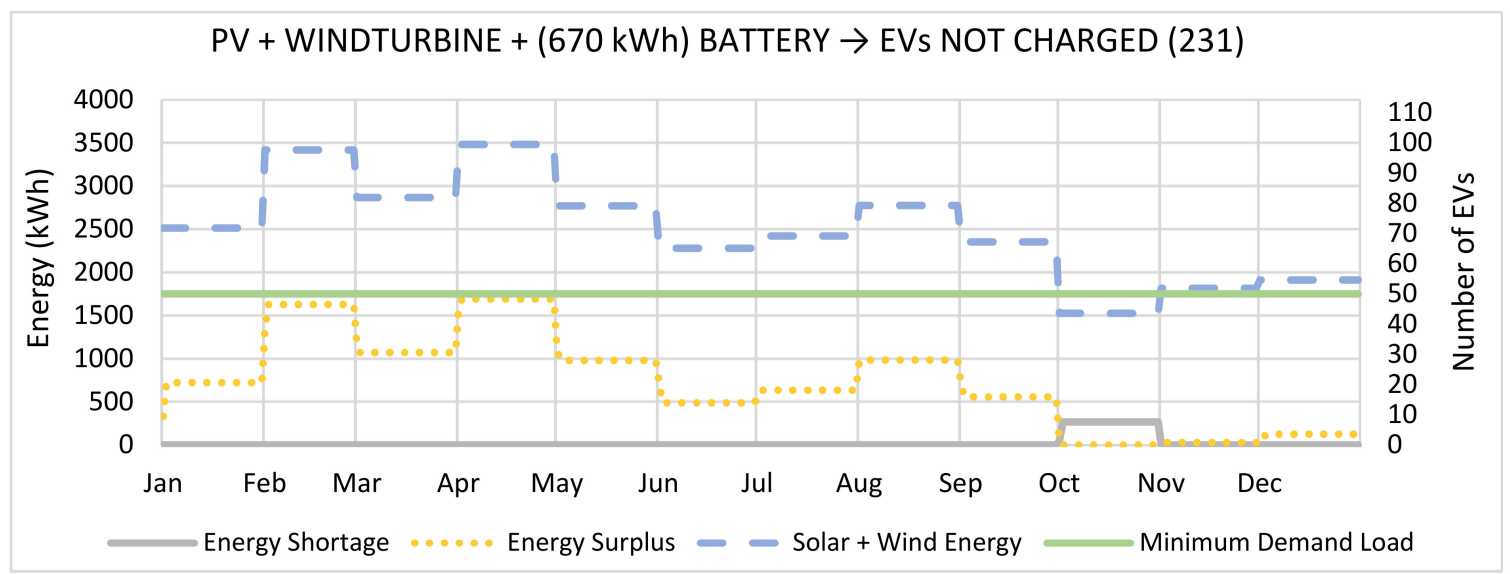

Figure 10. PV, WT and selected BSS size annual simulation results.

- Step two-optimal PV system selection: Since two types of PV systems-namely, PV panels and $\mathrm{CPV} / \mathrm{T}$ - are initially suggested by PVSyst, the developed program is used to investigate which one is the optimal choice after incorporating the wind turbine and the selected BSS size. Replacing the PV system with CPV/T reduces the number of EVs not able to be charged annually from 231 to 186 , which represents $1.02 \%$ of the annually targeted number of EVs. Moreover, the annual surplus energy from the system is increased considerably from 268,178 to 391,054 $\mathrm{kWh}$. This surplus energy is useful for decreasing the BSS capacity and producing the intended chemicals for energy storage purposes to assist in reducing or eliminating the supply shortage. Another advantage of incorporating the CPV/T subsystem in the design is the utilization of generated thermal energy as an input for an absorption cooling system. This could be used for BSS cooling to maintain its lifetime and reduce operational costs by preventing early BSS replacements. The results of this simulation step are shown in Figure 11.

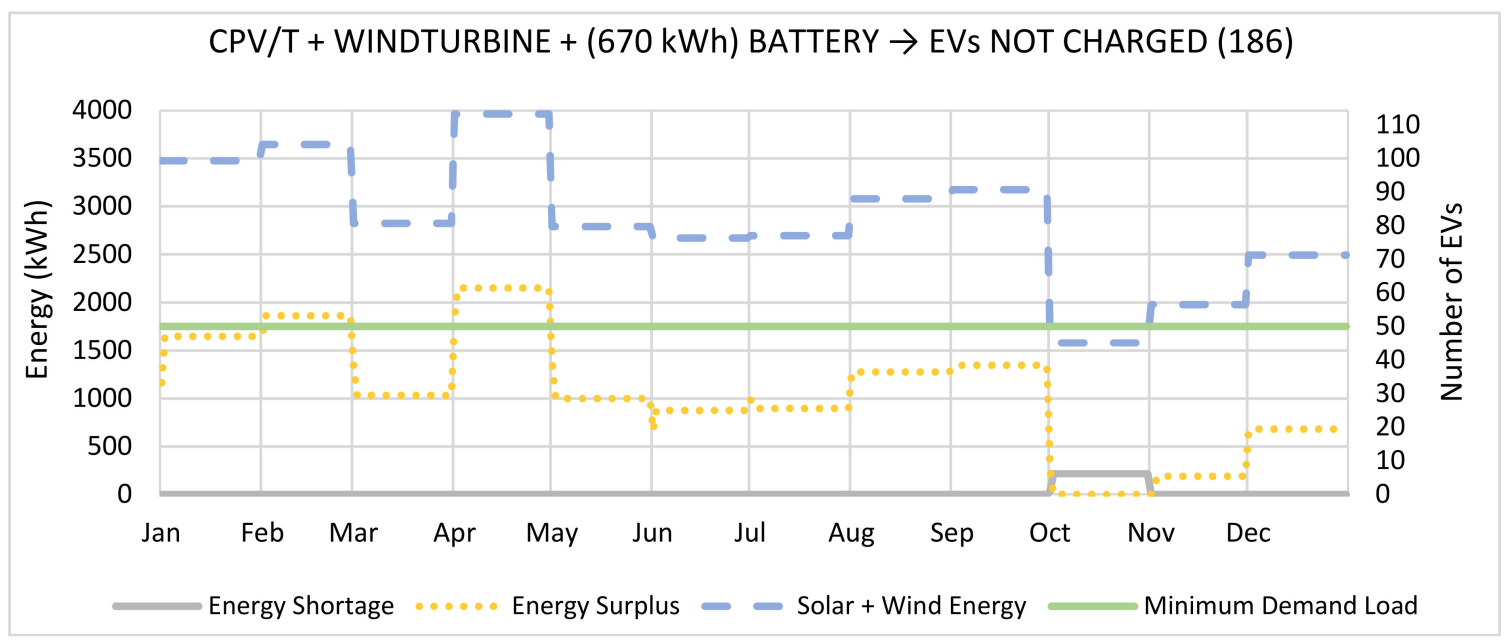

Figure 11. CPV/T, WT and selected BSS size annual simulation results.

- $\quad$ Step three-BSS size adjustment based on selected PV system: To better utilize the surplus energy produced by incorporating the $\mathrm{CPV} / \mathrm{T}$ subsystem, a $10 \%$ increase from the previously determined BSS capacity is simulated. Since the percentage of EVs that are not charged annually reduces to about $1 \%$, a following $10 \%$ size increase is simulated. Following the same criteria, multiple battery capacities are simulated by increasing the size by $10 \%$. In each iteration, if the percentage of EVs that not able to charge is reduced to more than 1\%, the next $10 \%$ size increase is simulated. Accordingly, an $811 \mathrm{kWh}$ battery capacity is determined as the optimal size, where the annual 
number of EVs that are not able to be charged is reduced to $182 \mathrm{EVs}$, which represents $1 \%$ of the annually targeted number of EVs. Since the next $10 \%$ battery size increase reduces this number by less than $1 \%$, no further battery size increase is considered beyond $811 \mathrm{kWh}$. Figure 12 demonstrates the simulation of the annual system operation and its results with the selected RES and BSS size so far.

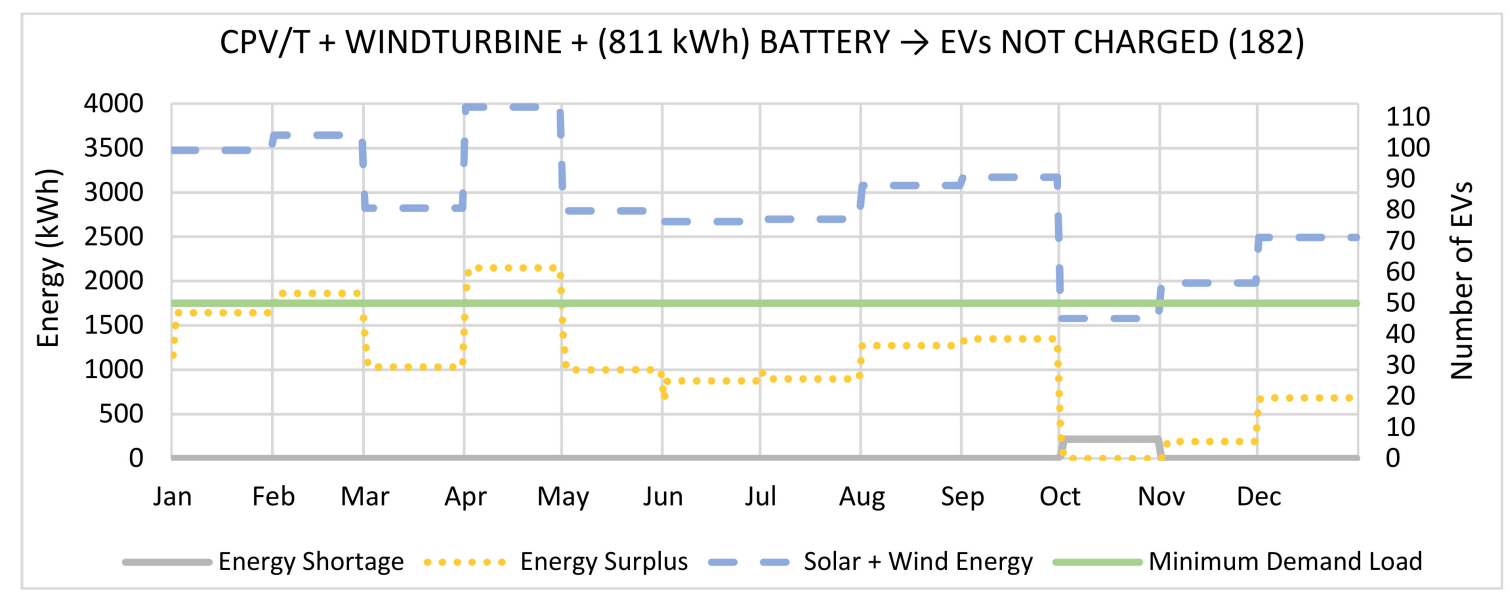

Figure 12. CPV/T, WT and amended BSS size annual simulation results.

- Step four-optimal bio-generator size selection: As indicated in Figure 12, there is no sufficient power supply available to fast charge 50 EVs daily during October with the current RES and BSS mix. A biofuel-driven generator is suggested as the third RES to be hybridized in the proposed design to eliminate this shortage. As per the simulation results of Figure 12, the maximum number of EVs that are not able to be charged in a day of October is six EVs. Since each EV needs $35 \mathrm{kWh}$ of charging power, six EVs represent a total $210 \mathrm{kWh}$ daily power shortage during October. With a $15 \%$ safety margin, a supplementary biofuel power generator capable of producing $250 \mathrm{kWh}$ in a day is required in the system. Since the biomass generator shall operate for $24 \mathrm{~h}$ during power shortage days, the appropriate biomass generator rating required for the system is found to be about $10 \mathrm{~kW}$. Figure 13 demonstrates the one-year system simulation and its results with the selected RES and BSS size so far, indicating zero EVs not able to be charged annually and $392,887 \mathrm{kWh}$ of yearly surplus energy from the system.

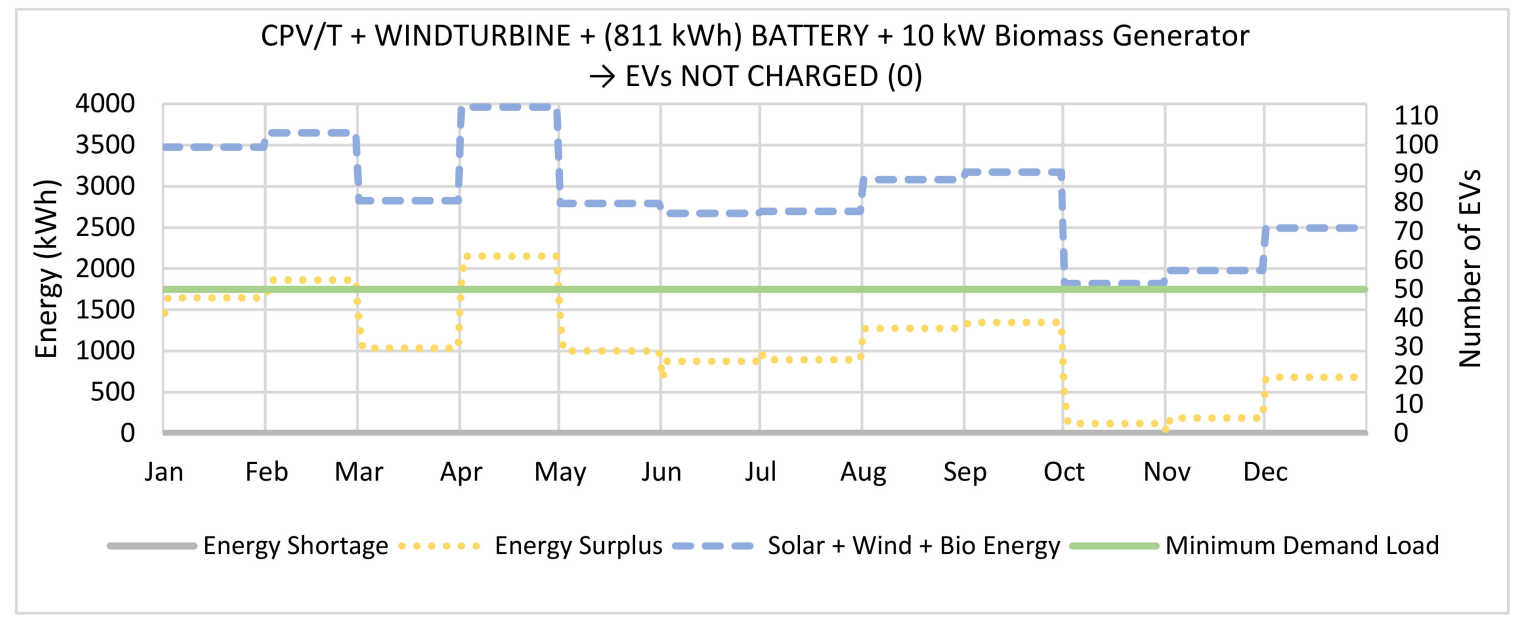

Figure 13. CPV/T, WT, biofuel power generator and BSS annual simulation results. 
- Step five-BSS size adjustment based on selected bio-generator: There could be an opportunity to reduce the selected BSS size via the addition of a biomass generator as a supplementary source. Starting with $811 \mathrm{kWh}$, multiple battery capacities are simulated through decreasing the size by $5 \%$ in each iteration. A $595 \mathrm{kWh}$ battery capacity is determined as the optimal size since it still allows all EVs to be charged. Nevertheless, any further decrease from this value creates a supply shortage. The annual simulation of the system with the obtained results is reflected in Figure 14.

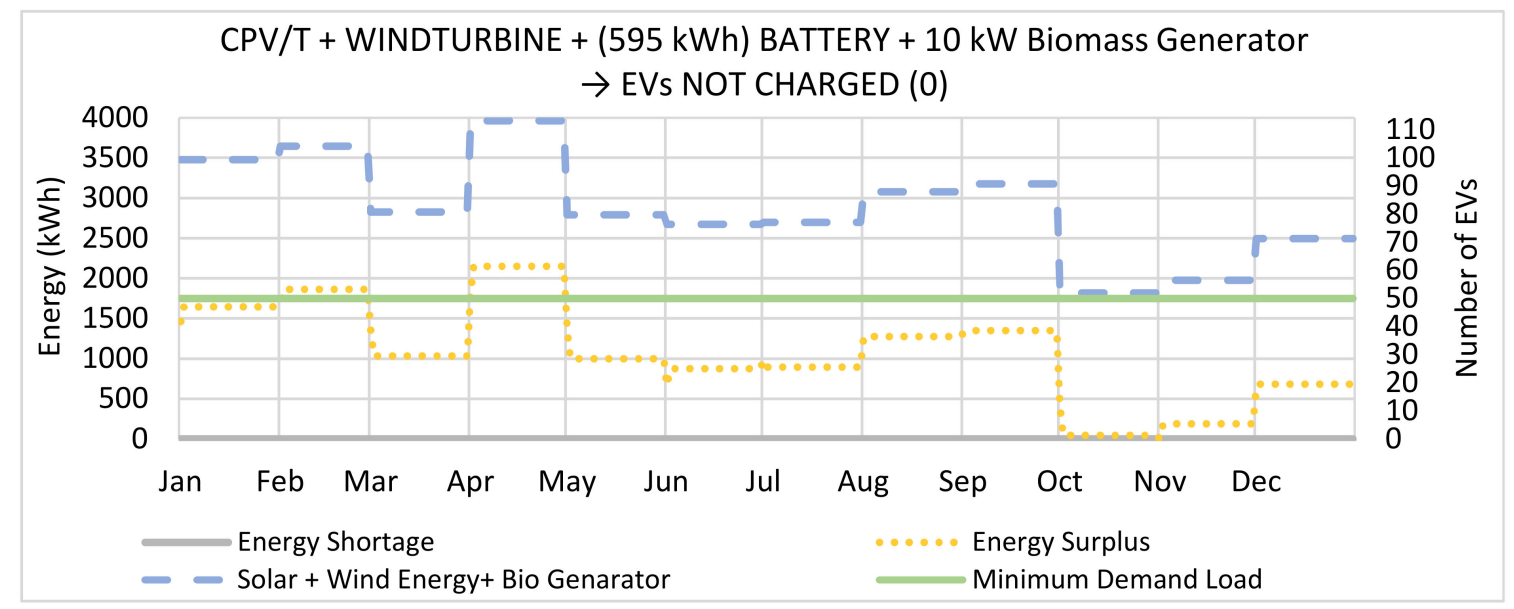

Figure 14. $\mathrm{CPV} / \mathrm{T}, \mathrm{WT}$, biofuel power generator and adjusted BSS annual simulation.

- Step six-optimal surplus energy amount selection for the chemical storage system (CSS): To sustain the continuous operation of the overall system during dark times and under various environmental circumstances, where RES supply is lessened or interrupted due to RES' intermittent and volatile nature, integrating chemical energy storage options complementing the BSS is studied. To secure the necessary power for producing the energy carrier chemicals, the optimal daily surplus energy that can be extracted from the system without compromising the minimum number of EVs able to be charged daily is investigated. Figure 15 depicts the monthly surplus energy generated from the integrated RES and BSS. Based on this, the daily optimal surplus energy shall be assessed and dedicated for a daily chemical production process.

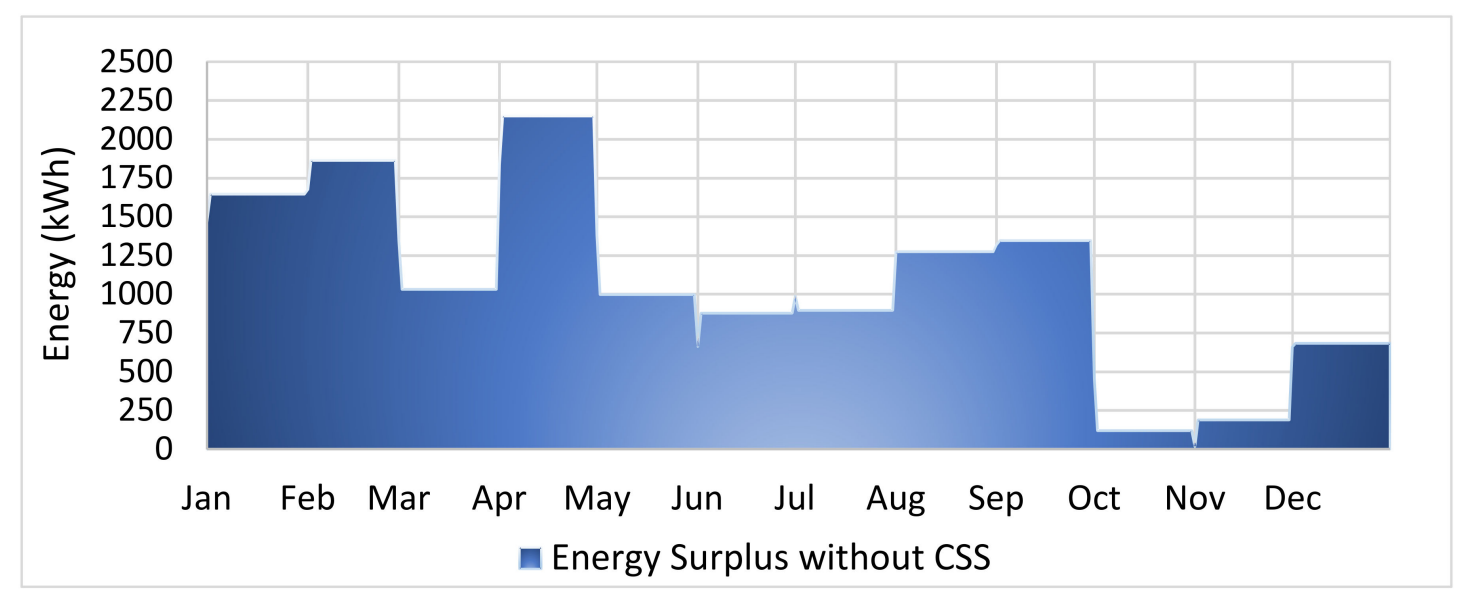

Figure 15. Available surplus energy from RES and BSS.

The optimal daily surplus energy is the fixed amount of surplus energy that can be extracted throughout the year with the minimum days of disruption and attaining the maximum amount of energy annually. Accordingly, the program is configured to simulate and calculate the total annual surplus energy that can be harvested at different energy levels selected from the monthly surplus 
energy spectrum. At each selected energy level, which represents the daily consumption capacity of the chemical production, the number of days where the surplus energy equals or exceeds the selected energy level is multiplied by the selected energy value to calculate the total annual surplus energy that can be extracted for the chemical production process. On the other hand, during the days where the surplus energy is less than the chemical production capacity, the surplus energy is kept ideal and the chemical production process is switched off during those days due to inadequate power availability.

Starting with the selection of the maximum monthly surplus energy, which occurs during April as illustrated in the first row of Table 3, the CSS, with the same consumption capacity, can be operated only during this month, while the CSS will be switched off due to the unavailability of the required energy for the rest of the year. The sum of the daily utilized surplus energy chemical production process is calculated and reflected in the last column of Table 3.

Table 3. Available daily surplus energy at various CSS capacities.

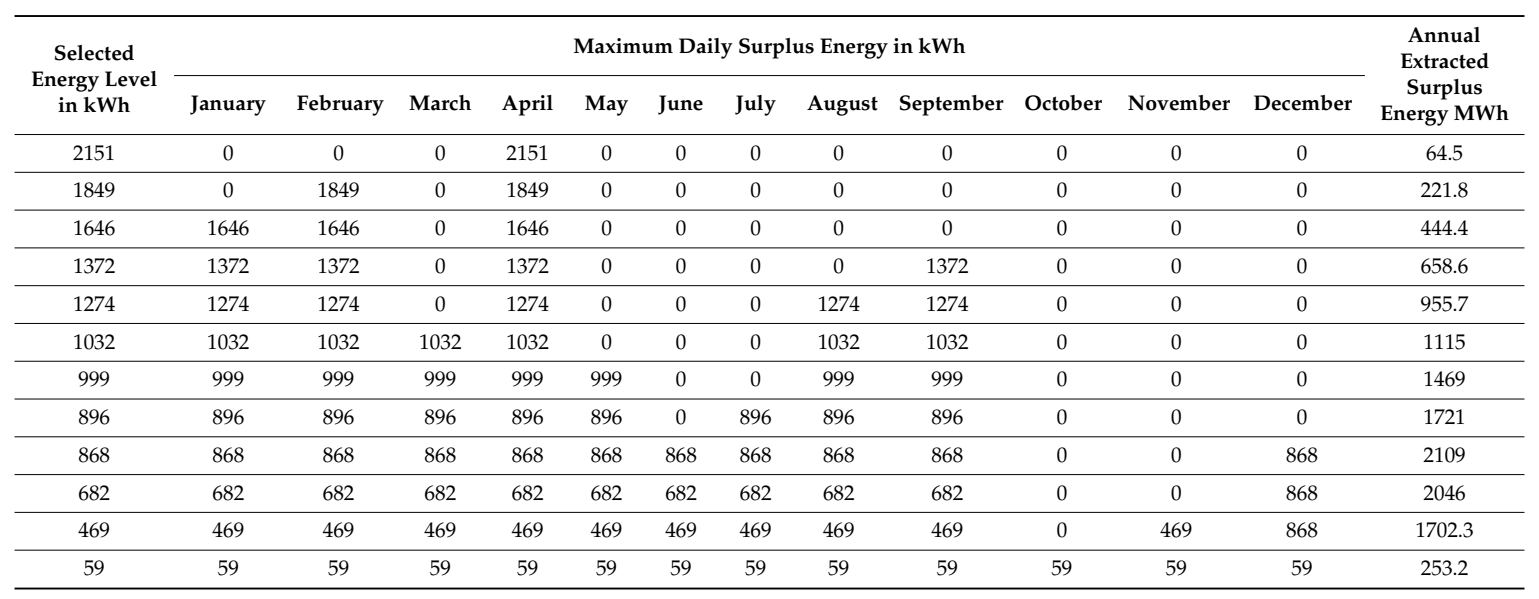

Following the same principle, the total annual extracted surplus energies for the rest of the selected energy levels are calculated and shown in Table 3. About $868 \mathrm{kWh}$ of energy capacity is found to be the optimal daily surplus energy, where the annual extracted surplus energy for CSS production totals $2109 \mathrm{MWh}$, which is the maximum value compared to the other selected energy levels as illustrated in Table 3.

Figure 16 shows that during the first nine months of the year, the CSS with an $868 \mathrm{kWh}$ capacity can be operated daily due to availability of sufficient surplus energy to run the system. However, during the last three months of the year, it cannot be operated daily due to unavailability of sufficient surplus energy caused by RES curtailment during these months.

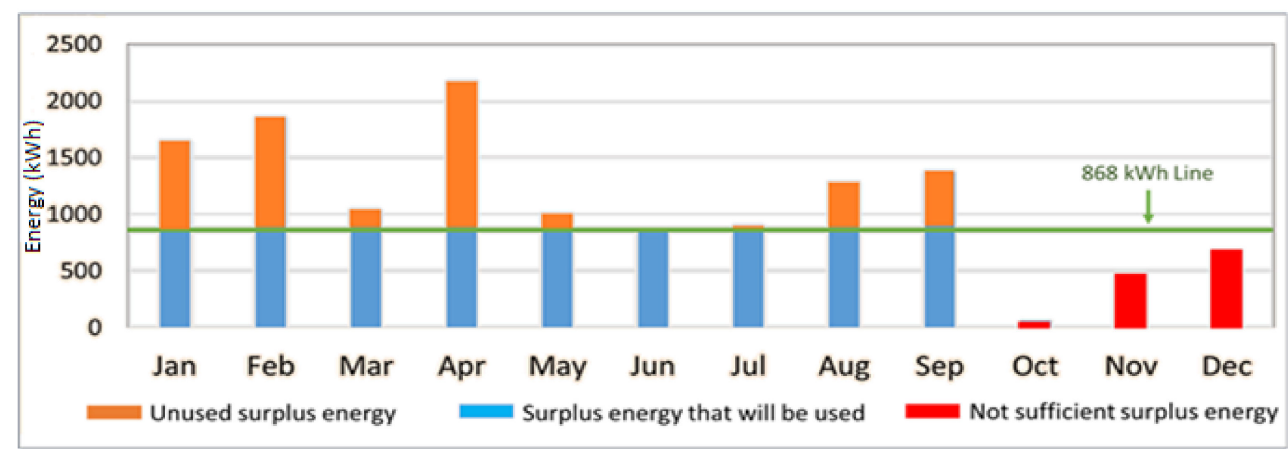

Figure 16. Selected CSS process energy capacity.

Accordingly, appropriate chemical production and storage systems with approximately $868 \mathrm{kWh}$ consumption capacities should be investigated and integrated within the design. In the study [31], 
a $\mathrm{H}_{2}$ and $\mathrm{NH}_{3}$ CSS consuming an $880 \mathrm{kWh}$ load was designed to generate $200 \mathrm{kWh}$ of electricity daily. The mass and storage tank volumes of $\mathrm{H}_{2}, \mathrm{NH}_{3}, \mathrm{~N}_{2}, \mathrm{O}_{2}$ and $\mathrm{H}_{2} \mathrm{O}$ for generating electricity with $\mathrm{H}_{2}$ and $\mathrm{NH}_{3}$ fuel cells as well as the total electricity requirements for producing the respective masses of $\mathrm{H}_{2}$ and $\mathrm{NH}_{3}$ from $\mathrm{H}_{2}$ and $\mathrm{NH}_{3} \mathrm{FCs}$ were determined using the EES software. Since the power required by the system proposed in our previous work [31] is equivalent to the available surplus power in this study, the same chemical system was incorporated and simulated in this design. As per the results demonstrated in Figure 17, the new load demand (EV daily charging demand and $\mathrm{H}_{2}$ and $\mathrm{NH}_{3}$ daily production demand) can be fulfilled with no deficit.

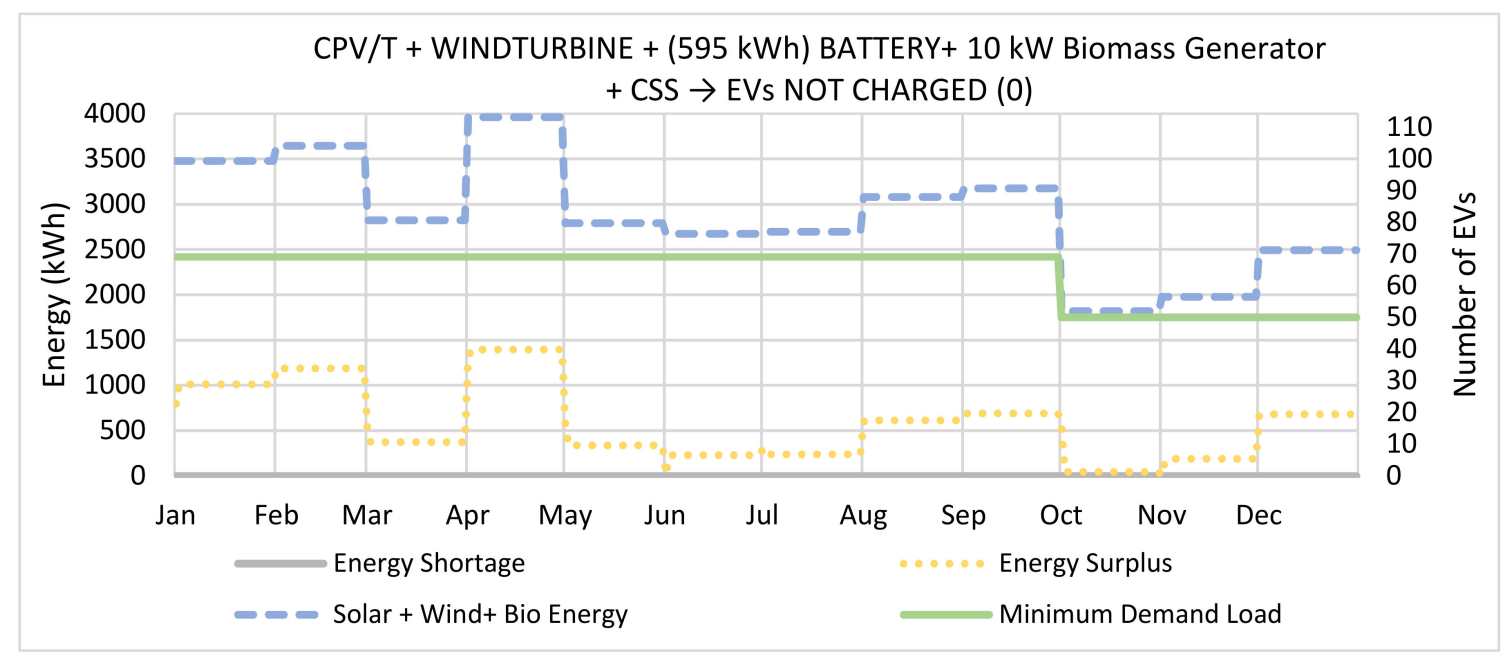

Figure 17. CPV/T, WT and bio-generator with BSS and CSS annual simulation results.

Figure 18 shows a comparison between the monthly surplus energy generated from the integrated system before and after incorporating the CSS, where the energy utilized for chemical production has decreased the ideal annual generated surplus energy from 392,857 to $210,336 \mathrm{kWh}$.

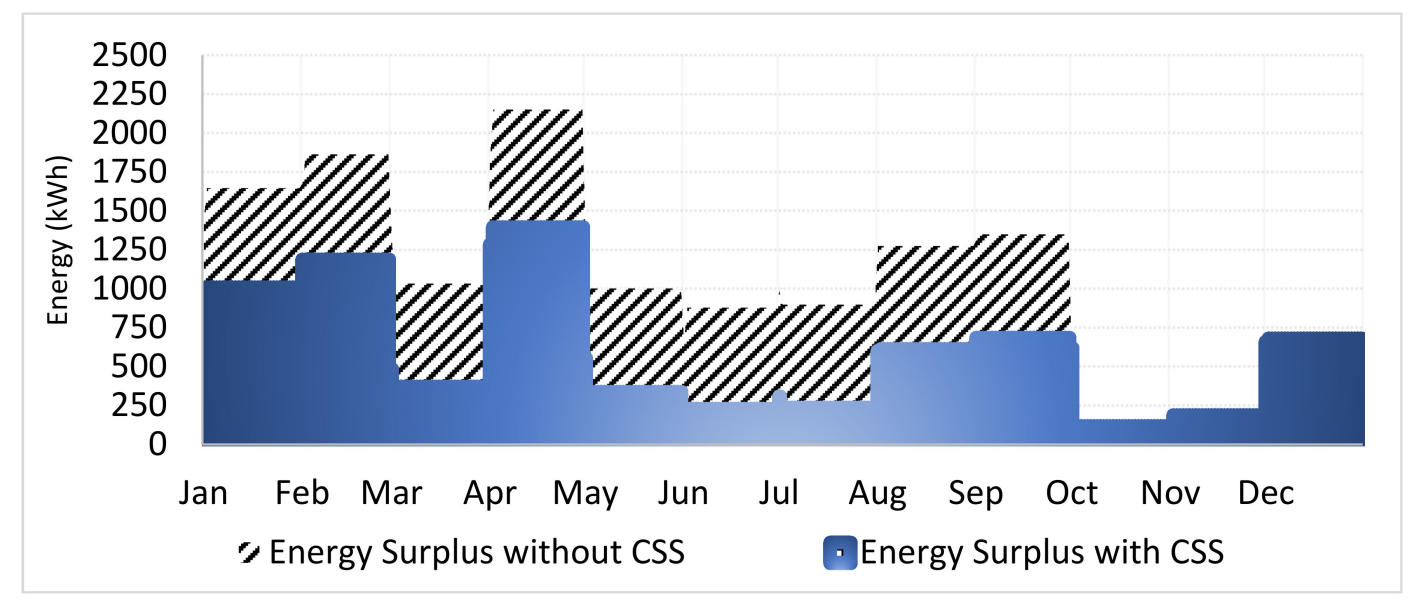

Figure 18. Monthly surplus energy from RES with BSS and CSS.

The $\mathrm{H}_{2}$ and $\mathrm{NH}_{3}$ produced from renewables in the system are used as an energy storage medium for timely conversion into electricity based on stochastic EV demand. Accordingly, fuel cells are incorporated in the design to convert the chemical energy embedded in the produced and stored $\mathrm{H}_{2}$ and $\mathrm{NH}_{3}$ to electrical energy through an electrochemical reaction. This is very useful for addressing demand shortages resulting from RES' intermittency and volatility. Unlike batteries, fuel cells do not need recharging once consumed and are considered to be more efficient than conventional cycles, where electricity is generated in one step with minimal maintenance due to non-moving parts [29]. In the proposed design, $\mathrm{H}_{2}$ and 
$\mathrm{NH}_{3}$ are produced, stored and then consumed in fuel cell subsystems for useful electricity production during night times and under unfavorable weather conditions.

- Step seven-optimal operation strategy for incorporated CSS: To further enhance the system's efficiency, the possibility for the partial operation of the integrated $\mathrm{H}_{2}$ and $\mathrm{NH}_{3}$ production capacity during the last three months of the year is investigated through multiple simulations, where several operating alternatives are tested. They are indicated in Table 4.

Table 4. Overall system monthly simulation with multiple CSS operational scenarios.

\begin{tabular}{ccccc}
\hline Simulation & Description & October & November & December \\
\hline \multirow{2}{*}{1} & CSS production capacity & $0 \%$ & $0 \%$ & $0 \%$ \\
\cline { 2 - 5 } & EVs not charged & 0 & 0 & 0 \\
\hline \multirow{2}{*}{2} & CSS production capacity & $25 \%$ & $25 \%$ & $25 \%$ \\
\cline { 2 - 5 } & EVs not charged & 96 & 5 & 0 \\
\hline \multirow{2}{*}{3} & CSS production capacity & $0 \%$ & $0 \%$ & $50 \%$ \\
\cline { 2 - 5 } & EVs not charged & 0 & 0 & 0 \\
\hline \multirow{2}{*}{4} & CSS production capacity & $0 \%$ & $0 \%$ & $75 \%$ \\
\cline { 2 - 5 } & EVs not charged & 0 & 0 & 1 \\
\hline
\end{tabular}

The results in Table 4 show that operating the CSS with 25\% capacity during the last three months would result in a charging deficit of 96 EVs in October and five EVs in November. Keeping the system off during October and November while operating with 50\% capacity during December would not cause any charging deficits. On the other hand, increasing the operating capacity to $75 \%$ in last month would cause a charging shortage.

Figure 19 compares the monthly generated surplus energy during normal CSS operation against that during optimized operation, where the ideal generated annual surplus energy from the overall system is reduced from 210,336 to $200,028 \mathrm{kWh}$. This is due to an additional extracted surplus energy during December for CSS half-capacity production.

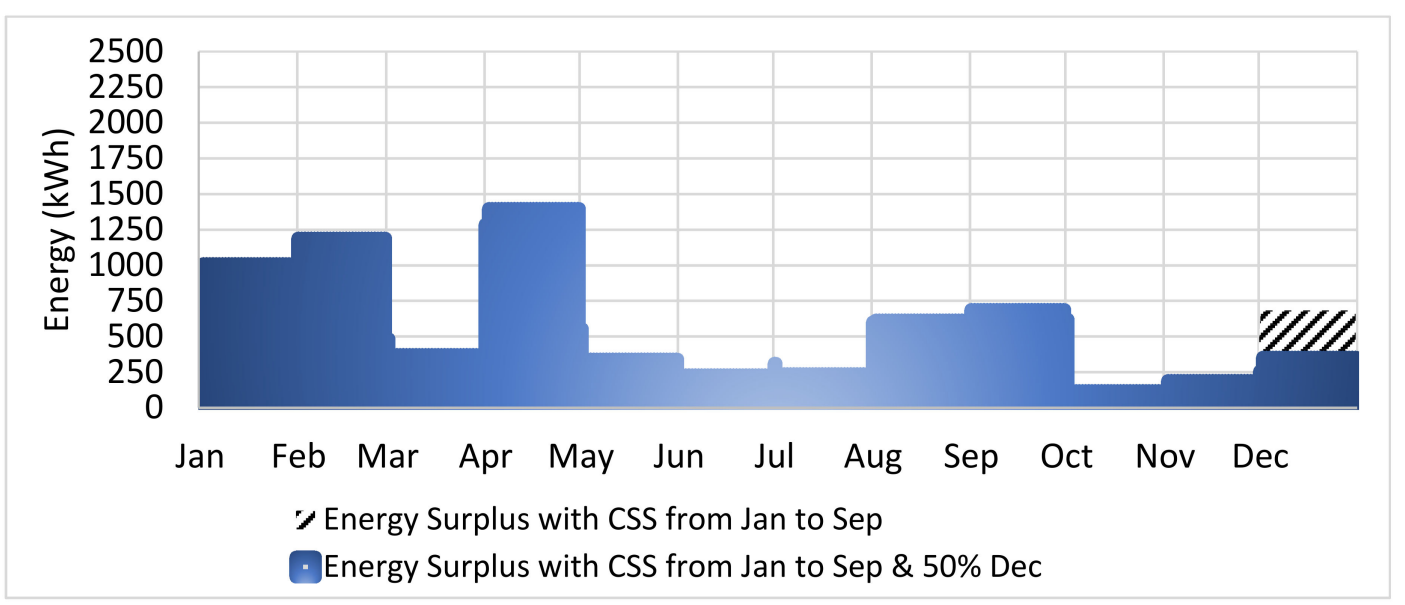

Figure 19. Monthly surplus energy from RES with BSS and optimized operation of CSS.

The $200 \mathrm{~kW}$ generated from January to September and the $100 \mathrm{~kW}$ generated during December from the CSS cannot assist in reducing the BSS size further since any reduction will cause supply shortages during October and November when the CSS is kept off. However, the number of BSS charging and discharging cycles is dropped by $38 \%$, from 221 to 136 cycles yearly, contributing in extending the lifetime of the BSS and increasing the overall system's economic feasibility. 
The annual simulation results for the final overall design consisting of an integrated $468 \mathrm{kWp}$ CPV/T, $250 \mathrm{~kW} \mathrm{WT,} 10 \mathrm{~kW}$ biomass generator, $595 \mathrm{kWh}$ BSS and $200 \mathrm{~kW}$ CSS are illustrated in Figure 20, where the objective function, constraints and study's objectives are all fulfilled.

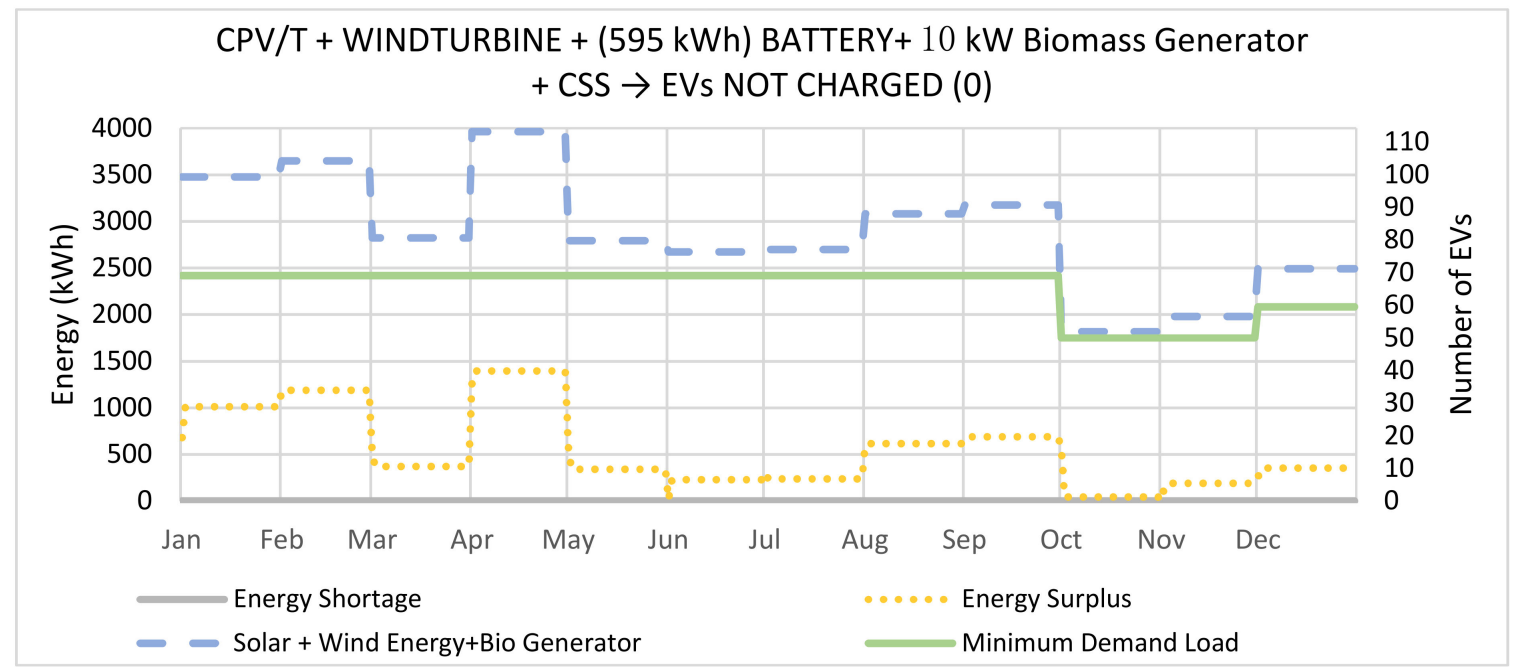

Figure 20. Overall system's annual simulation results with the optimized operation of the CSS.

Based on the detailed simulation results for the overall system for a year, the average daily production by RES and consumption by EVs and CSS are reflected in Table 5, and the amount of energy supplied by each source in the system for EV charging is reflected in Table 6.

Table 5. Average daily produced and consumed energy.

\begin{tabular}{|c|c|}
\hline Description & Energy (kWh) \\
\hline \multicolumn{2}{|c|}{ Average Daily Produced Energy } \\
\hline $\mathrm{CPV} / \mathrm{T}$ & 1385.94 \\
\hline WT & 1471.09 \\
\hline Bio-generator & 40.11 \\
\hline Average daily produced energy & 2897.14 \\
\hline \multicolumn{2}{|c|}{ Average Daily Consumed Energy } \\
\hline EV charging & 1750 \\
\hline $\mathrm{H}_{2}$ production & 404.69 \\
\hline $\mathrm{NH}_{3}$ production & 280.60 \\
\hline $\begin{array}{l}\text { Average daily consumed } \\
\text { energy }\end{array}$ & 2435.29 \\
\hline
\end{tabular}

Table 6. Average daily EV charging energy by source.

\begin{tabular}{|c|c|}
\hline Source & Energy (kWh) \\
\hline $\mathrm{CPV} / \mathrm{T}$ & 625.38 \\
\hline WT & 813.61 \\
\hline BSS & 168.05 \\
\hline $\mathrm{H}_{2} \mathrm{FC}$ & 73.70 \\
\hline $\mathrm{NH}_{3} \mathrm{FC}$ & 67.65 \\
\hline Average daily produced energy & 1748.39 \\
\hline
\end{tabular}




\section{Environmental and Economic Perspective Highlights}

The focus of the study is on the technical aspects of the proposed stand-alone renewable energy-based fast charging station, where the energy produced and consumed is investigated through modeling and simulation to achieve the optimal energy management of the overall system. However, it is worth highlighting the economic and environmental aspects of the proposed off-grid design through a fundamental comparison with a grid-connected charging station, which is covered below.

- Environmental perspective highlights: Integrating RES as alternative options for supplying EV charging stations instead of connecting them to a fossil fuel-based grid would contribute significantly to reducing GHG emissions. This would positively impact the environment and public health in general. Since natural gas is used as fuel for generating electricity in Qatar, Table 7 compares the carbon emissions generated by drawing the required energy from the grid against those generated by a grid-independent RES-based charging station.

Table 7. Grid-connected vs. RES-based, grid-independent charging station $\mathrm{CO}_{2}$ emissions during operation.

\begin{tabular}{ccccc}
\hline Supply Source & $\begin{array}{c}\text { Annual Production } \\
\mathbf{( k W h )}\end{array}$ & $\begin{array}{c}\mathrm{CO}_{\mathbf{2}} \text { Emissions } \\
\left(\mathrm{CO}_{2} / \mathbf{k W h}\right)\end{array}$ & $\begin{array}{c}\text { Annual } \mathrm{CO}_{2} \text { Emissions } \\
\left(\mathrm{CO}_{2} / \mathbf{k W h}\right)\end{array}$ & Reference \\
\hline Grid-connected charging station & & [37] \\
\hline Biodiesel power generator & 638,750 & 0.181 & $\mathbf{1 1 5 , 6 1 3}$ & {$[37]$} \\
\hline CPV/T & 14,640 & 0.250 & 3660 & \\
\hline Wind & 505,867 & 0 & 0 & {$[37]$} \\
\hline
\end{tabular}

As per the above comparison, the annual $\mathrm{CO}_{2}$ emissions produced from the proposed system are only 3.66 tons, while 115.61 tons of $\mathrm{CO}_{2}$ emissions are produced from a grid-connected charging station where only natural gas is used, annually, to serve the same number of EVs per year.

- Economic perspective highlights: To highlight the economic aspects of deploying a renewable energy-based distributed generation system for satisfying fast EV charging station demand rather than connecting to the grid, the range of the Levelized Cost of Electricity (LCOE) for each of the incorporated renewable energy subsystems in the design is acquired from the literature to estimate the LCOE for the overall system. Based on the data downloaded from Open Energy Information Database [38], a box-and-whisker plot is illustrated in Figure 21 to help analyze the acquired data.

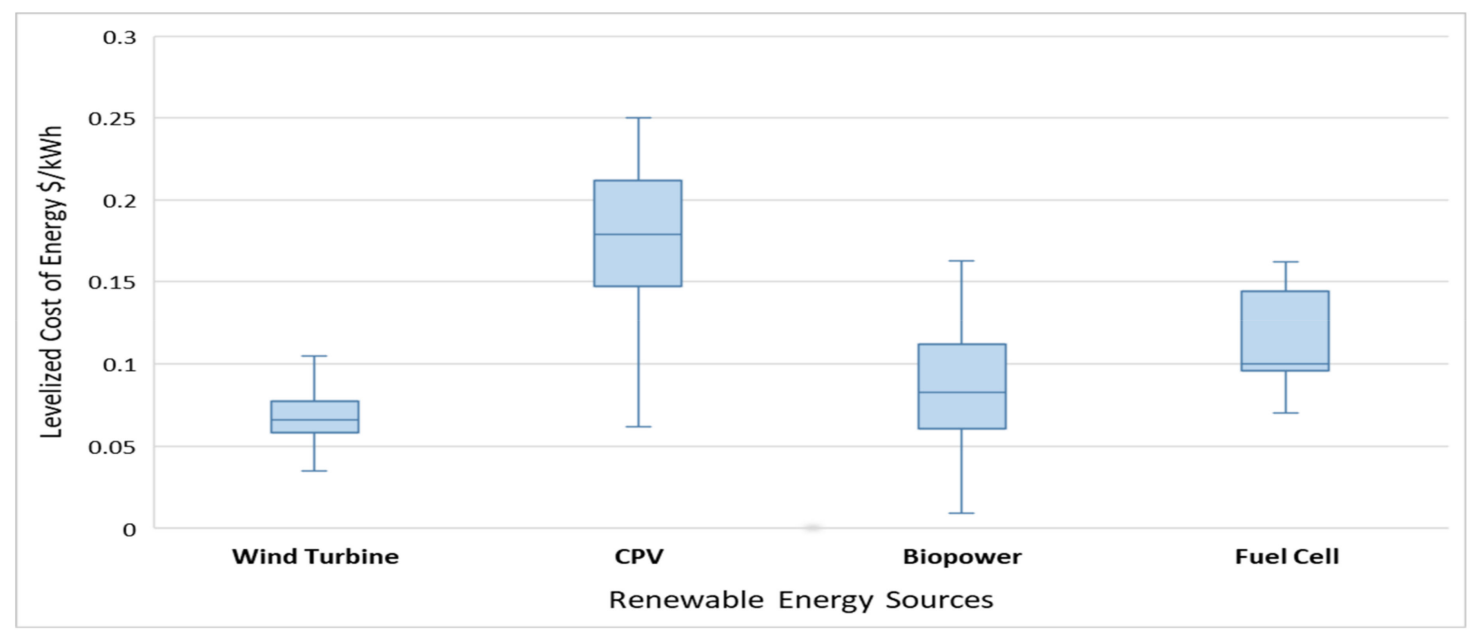

Figure 21. Levelized Cost of Energy range of incorporated RES (data from [38]). 
The first-and-third-quartile LCOE range of the WT is found to be USD 0.06-0.08/kWh, that of CPV is found to be USD $0.15-0.21 / \mathrm{kWh}$, and that of biopower is found to be USD $0.06-0.1 / \mathrm{kWh}$. Based on the amount of energy annually produced by the WT, CPV and bio-generator shown in Table 7, the estimated LCOE range of the overall system is calculated and found to be USD 0.10-0.14/kWh. Comparing this range with the subsidized tariff in Qatar, which is USD 0.09/kWh [39], it is found to be $10-55 \%$ higher. However, considering imposing a non-subsidized tariff and imposing carbon taxes on grid-dependent CS owners will make the proposed project feasible from an economic perspective.

\section{Conclusions and Future Work}

This study aimed to simulate the optimal energy management of a stand-alone charging station with hybridized multiple RES and sustainable storage systems to fast-charge a minimum of 50 EVs per day. The study investigated the optimal ratings of the solar, wind and biofuel power generator units to be integrated in the design, along with the optimal electrochemical and chemical storage capacities to fulfill the daily power demands in Qatar, with harsh climate conditions. Some of the main results of the study include the followings:

- The selection of a $468 \mathrm{kWp}$ CPV/T plant, $250 \mathrm{~kW}$ wind turbine and $10 \mathrm{~kW}$ biofuel power generator with a $595 \mathrm{kWh}$ BSS is sufficient for producing the power needed to satisfy demand for fast-charging 50 EVs daily throughout the year without interruption.

- Replacing the PV system with a CPV/T reduced the annual number of EVs not able to be charged by $20 \%$ and increased the annual surplus energy by $46 \%$, useful for energy storage for night times and utilization under unfavorable weather conditions.

- A $10 \mathrm{~kW}$ backup bio-generator was incorporated to eliminate the $1 \%$ annual number of EVs not able to be charged during October, which was operated on $24 \mathrm{~h}$ basis during this month only.

- To enhance the system reliability under unfavorable conditions, $880 \mathrm{kWh}$ of ideal surplus energy generated from RES was dedicated for daily $\mathrm{H}_{2}$ and $\mathrm{NH}_{3}$ production from January to September to integrate the CSS without compromising the minimum number of EVs able to be charged daily.

- Due to RES curtailment during the last 3 months of the year, the total shutdown of the CSS during October and November, with 50\% operation capacity during December, was adopted as an operational strategy to achieve optimal energy management.

- The extracted surplus energy produced, $200 \mathrm{~kW}$ daily from January to September and $100 \mathrm{~kW}$ daily during December, assisted in reducing the charging and discharging cycles for the BSS by $38 \%$, extending its lifetime and economic feasibility.

- The proposed grid-independent CS produces 3.66 tons of $\mathrm{CO}_{2}$ emissions annually vs. the 115.61 tons of $\mathrm{CO}_{2}$ emissions produced annually from a grid-connected charging station to serve the same number of EVs per year.

The estimated LCOE range of the overall system was found to be USD $0.10-0.14 / \mathrm{kWh}$, while the subsidized tariff in Qatar is USD 0.09/kWh. However, considering a potential non-subsidized tariff and imposing carbon taxes on grid-dependent CS owners would make the project feasible.

It is worth considering the following areas as future work following this study:

- This paper is considered as detailed technical assessment study without focusing on the economic and environmental aspects of the proposed design. It is worth performing a detailed economic and environmental assessment of the proposed design to ensure its overall feasibility.

- The study simulation and results are based on hourly supply-and-demand representation, where sudden minute-by-minute changes are not considered. Future work based on minute-by-minute generation, load profiles and simulation is recommended, where demand changes during weekends and holidays must be considered to further validate the results of this study.

- Since the conducted modeling, simulation and optimization study is for an off-grid design, microgrid concept was not considered. Multiple nearby charging stations sharing a decentralized renewable energy-based power generation system through a microgrid are recommended for future study. 
Author Contributions: Conceptualization, Y.B.; Methodology, Y.B., A.A.W.; Software, Y.B., A.A.W.; Formal Analysis, A.A.W.; Investigation, A.A.W.; Resources, Y.B.; Data Curation, A.A.W., Y.B.; Writing-Original Draft Preparation, A.A.W.; Writing-Review \& Editing, A.A.W., Y.B.; Supervision, Y.B. All authors have read and agreed to the published version of the manuscript.

Funding: The APC of this article was funded by the Qatar National Library. This research was funded by Qatar Foundation with student number 210009262.

Acknowledgments: The authors acknowledge the support from the Hamad Bin Khalifa University (HBKU) and Qatar Foundation (QF), the wind data from the Supreme Committee for Delivery \& Legacy and the help from Engr. Mazan Al Masri at the Qatar Electricity and Water Corporation (KAHRAMAA).

Conflicts of Interest: The authors declare that they have no known competing financial interests or personal relationships that could have appeared to influence the work reported in this paper.

\section{Nomenclature}

$\begin{array}{ll}\text { APSO } & \text { Adaptive Particle Swarm Optimization } \\ \text { BSS } & \text { Battery Storage System } \\ \text { CS } & \text { Charging Stations } \\ \text { CPV/T } & \text { Concentrated Photovoltaic Thermal } \\ \text { CSS } & \text { Chemical Storage System } \\ \text { EES } & \text { Engineering Equation Solver } \\ \text { EV } & \text { Electric Vehicles } \\ \text { FC } & \text { Fuel Cell } \\ \text { FCS } & \text { Fast Charging Stations } \\ \text { GA } & \text { Generic Algorithm } \\ \text { GHG } & \text { Greenhouse gases } \\ \text { HHV } & \text { Higher heating value } \\ \text { LCOE } & \text { Levelized Cost of Electricity } \\ \text { Li-ion } & \text { Lithium Ion } \\ \text { MILP } & \text { Mixed-Integer Linear Programming } \\ \text { MINLP } & \text { Mixed-Integer Non-Linear Programing } \\ \text { PE } & \text { Produced Electricity } \\ \text { PSO } & \text { Particle Swarm Optimization } \\ \text { PV } & \text { Photovoltaic } \\ \text { RES } & \text { Renewable Energy Sources } \\ \text { SoC } & \text { State of Charge } \\ \text { SPA } & \text { Set Pair Analysis } \\ \text { USD } & \text { United States Dollar } \\ \text { WT } & \text { Wind Turbine } \\ & \end{array}$

\section{References}

1. Grande, L.A.; Yahyaoui, I.; Gómez, S.A. Energetic, economic and environmental viability of off-grid PV-BESS for charging electric vehicles: Case study of Spain. Sustain. Cities Soc. 2018, 37, 519-529. [CrossRef]

2. Dicks, G.; Breedon, F. World Outlook; International Energy Agency (IEA): Paris, France, 1988.

3. Girard, A.; Roberts, C.; Simon, F.; Ordoñez, J. Solar electricity production and taxi electrical vehicle conversion in Chile. J. Clean. Prod. 2019, 210, 1261-1269. [CrossRef]

4. Mozafar, M.R.; Moradi, M.H.; Amini, M.H. A simultaneous approach for optimal allocation of renewable energy sources and electric vehicle charging stations in smart grids based on improved GA-PSO algorithm. Sustain. Cities Soc. 2017, 32, 627-637. [CrossRef]

5. Wu, D.; Radhakrishnan, N.; Huang, S. A hierarchical charging control of plug-in electric vehicles with simple flexibility model. Appl. Energy 2019, 253, 113490. [CrossRef]

6. Domínguez-Navarro, J.A.; Dufo-López, R.; Yusta, J.M.; Sevil, S.A.-J.; Bernal-Agustín, J.L. Design of an electric vehicle fast-charging station with integration of renewable energy and storage systems. Int. J. Electr. Power Energy Syst. 2019, 105, 46-58. [CrossRef] 
7. Gong, L.; Cao, W.; Liu, K.; Yu, Y.; Zhao, J. Demand responsive charging strategy of electric vehicles to mitigate the volatility of renewable energy sources. Renew. Energy 2020, 156, 665-676. [CrossRef]

8. Goli, P.; Shireen, W. PV powered smart charging station for PHEVs. Renew. Energy 2014, 66, 280-287. [CrossRef]

9. Gouveia, J.P.; Dias, L.; Martins, I.; Seixas, J. Effects of renewables penetration on the security of Portuguese electricity supply. Appl. Energy 2014, 123, 438-447. [CrossRef]

10. Hung, D.Q.; Mithulananthan, N.; Bansal, R. An optimal investment planning framework for multiple distributed generation units in industrial distribution systems. Appl. Energy 2014, 124, 62-72. [CrossRef]

11. Davda, A.T.; Azzopardi, B.; Parekh, B.R.; Desai, M.D. Dispersed Generation Enable Loss Reduction and Voltage Profile Improvement in Distribution Network-Case Study, Gujarat, India. IEEE Trans. Power Syst. 2013, 29, 1242-1249. [CrossRef]

12. Amini, M.H.; Moghaddam, M.P.; Karabasoglu, O. Simultaneous allocation of electric vehicles' parking lots and distributed renewable resources in smart power distribution networks. Sustain. Cities Soc. 2017, 28, 332-342. [CrossRef]

13. Liu, Z.; Zhang, W.; Ji, X.; Li, K. Optimal Planning of charging station for electric vehicle based on particle swarm optimization. In IEEE PES Innovative Smart Grid Technologies; IEEE: Piscataway, NJ, USA, 2012; pp. 1-5.

14. Sadeghi-Barzani, P.; Rajabi-Ghahnavieh, A.; Kazemi-Karegar, H. Optimal fast charging station placing and sizing. Appl. Energy 2014, 125, 289-299. [CrossRef]

15. Haddadian, G.; Khalili, N.R.; Khodayar, M.E.; Shahidehpour, M. Optimal coordination of variable renewable resources and electric vehicles as distributed storage for energy sustainability. Sustain. Energy Grids Netw. 2016, 6, 14-24. [CrossRef]

16. CJin, C.; Sheng, X.; Ghosh, P. Optimized Electric Vehicle Charging with Intermittent Renewable Energy Sources. IEEE J. Sel. Top. Signal Process. 2014, 8, 1063-1072.

17. Liu, H.; Zeng, P.; Guo, J.; Wu, H.; Ge, S. An optimization strategy of controlled electric vehicle charging considering demand side response and regional wind and photovoltaic. J. Mod. Power Syst. Clean Energy 2015, 3, 232-239. [CrossRef]

18. Mehrjerdi, H. Off-grid solar powered charging station for electric and hydrogen vehicles including fuel cell and hydrogen storage. Int. J. Hydrogen Energy 2019, 44, 11574-11583. [CrossRef]

19. Karmaker, A.K.; Ahmed, R.; Hossain, A.; Sikder, M. Withdrawn: Feasibility assessment and design of hybrid renewable energy based electric vehicle charging station in Bangladesh. Data Brief. 2018, 39, 189-202. [CrossRef]

20. The HOMER microgrid software Pro 2018. Available online: http://www.homerenergy.com (accessed on 26 July 2019).

21. P.S.A. State of Qatar Goverment Monthly. Figures on Total Population. June 2019. Available online: https: //www.mdps.gov.qa/en/statistics1/Pages/population.aspx (accessed on 26 July 2019).

22. Hukoomi. About Qatar. 2015; pp. 1-2. Available online: https://portal.www.gov.qa/wps/portal/about-qatar (accessed on 26 July 2019).

23. CEIC. Number of Registered Motor Vehicles in Qatar. 2019. Available online: https://www.ceicdata.com/en/ qatar/number-of-registered-motor-vehicles/number-of-registered-motor-vehicles (accessed on 26 July 2019).

24. The Peninsula Qatar. Qatar aims to increase electric cars to 10\%. The Peninsula Qatar, Online, Doha, 9 May 2017. Available online: https://www.thepeninsulaqatar.com/article/09/05/2017/Qatar-aims-to-increase-electric-cars-to10 (accessed on 26 July 2019).

25. Qana, D. Qatar Aims to Reach 10\% Green Cars by 2030; Lusailnews: Doha, Qatar, 2017.

26. Sachin, K. 400 electric car charging stations by 2022 in Qatar. The Peninsula Qatar, Online, Doha. 17 January 2019. Available online: https:/www.thepeninsulaqatar.com/article/17/01/2019/400-electric-car-charging-stations-by2022-in-Qatar (accessed on 26 July 2019).

27. Sokorai, P.; Fleischhacker, A.; Lettner, G.; Auer, H. Stochastic Modeling of the Charging Behavior of Electromobility. World Electr. Veh. J. 2018, 9, 44. [CrossRef]

28. Lokesh, B.T.; Min, J.T.H. A Framework for Electric Vehicle (EV) Charging in Singapore. Energy Procedia 2017, 143, 15-20. [CrossRef]

29. Dincer, I.; Bicer, Y. Integrated Energy Systems for Multigeneration; Elsevier: Amsterdam, The Netherlands, 2020.

30. Al Wahedi, A.; Bicer, Y. Development of an off-grid electrical vehicle charging station hybridized with renewables including battery cooling system and multiple energy storage units. Energy Rep. 2020, 6, 2006-2021. [CrossRef] 
31. Klein. EES: Engineering Equation Solver. F-Chart Software: Engineering Software; F-Chart Software: Madison, WI, USA, 2018.

32. PVsyst 6.7.8 Software. 2018. Available online: https://www.pvsyst.com (accessed on 26 July 2019).

33. Wind-Turbine-Models.com. EWT DW 54-250-250,00 kW-Wind Turbine. Available online: https://en.windturbine-models.com/turbines/1538-ewt-dw-54-250 (accessed on 6 January 2020).

34. Méndez, C.; Bicer, Y. Qatar's Wind Energy Potential with Associated Financial and Environmental Benefits for the Natural Gas Industry. Energies 2019, 12, 3329. [CrossRef]

35. Qatar Civil Aviation Authority. Available online: https://www.caa.gov.qa/en-us/Pages/Metrogical.aspx (accessed on 25 August 2020).

36. Bayram, I.S.; Zamani, V.; Hanna, R.; Kleissl, J. On the evaluation of plug-in electric vehicle data of a campus charging network. In 2016 IEEE International Energy Conference (ENERGYCON); Institute of Electrical and Electronics Engineers (IEEE): Piscataway, NJ, USA, 2016; pp. 1-6.

37. Méndez, C.; Bicer, Y. Wind energy potential of Qatar for power generation with associated financial and environmental benefits for natural gas industry. Energies 2019. under review.

38. Open Energy Information. LCOE. Available online: https://openei.org/apps/TCDB/\#blank (accessed on 25 August 2020).

39. Qatar General Electricity and Water Corporation. "KAHRAMAA", Electricity and Water Tariff in Qatar. Available online: https://www.km.qa/CustomerService/Pages/Tariff.aspx (accessed on 25 August 2020).

(C) 2020 by the authors. Licensee MDPI, Basel, Switzerland. This article is an open access article distributed under the terms and conditions of the Creative Commons Attribution (CC BY) license (http://creativecommons.org/licenses/by/4.0/). 